\title{
Quality standard of traditional Chinese medicines: comparison between European Pharmacopoeia and Chinese Pharmacopoeia and recent advances
}

\author{
Fong Leong ${ }^{1 \dagger}$, Xue Hua ${ }^{1 \dagger}$, Mei Wang ${ }^{2}$, Tongkai Chen ${ }^{3}$, Yuelin Song ${ }^{4}$, Pengfei Tu ${ }^{4,5}$ and Xiao-Jia Chen ${ }^{1^{*}}$ (1)
}

\begin{abstract}
Traditional Chinese medicine (TCM) are becoming more and more popular all over the world. However, quality issues of TCM may lead to medical incidents in practice and therefore quality control is essential to TCM. In this review, the state of TCM in European Pharmacopoeia are compared with that in Chinese Pharmacopoeia, and herbal drugs that are not considered as TCM and not elaborated by TCM working party at European Directorate for the Quality of Medicines \& Health Care (EDQM) but present in both European Pharmacopoeia and Chinese Pharmacopoeias are also discussed. Different aspects in quality control of TCM including origins, identification, tests and assays, as well as sample preparation, marker selection and TCM processing are covered to address the importance of establishing comprehensive quality standard of TCM. Furthermore, advanced analytical techniques for quality control and standard establishment of TCM are also reviewed.
\end{abstract}

Keywords: Traditional Chinese medicine, European Pharmacopoeia, Chinese Pharmacopoeia, Quality standard

\section{Background}

Application of herbal drugs or herbal therapies could be dated back since ancient times of human history and it is still being practiced in many places all over the world [1]. Among the herbal drugs applied worldwide, traditional Chinese medicines (TCM) is a large group of plants, animals or minerals applied in remedies following the medical principles developed in ancient China. Nowadays, with system scientific research and modern production technologies, more and more people worldwide

\footnotetext{
*Correspondence: xiaojiachen@um.edu.mo

${ }^{\dagger}$ Fong Leong and Xue Hua contributed equally to this work

${ }^{1}$ State Key Laboratory of Quality Research in Chinese Medicine,

Institute of Chinese Medical Sciences, University of Macau, Avenida da

Universidade, Taipa, Macao, People's Republic of China

Full list of author information is available at the end of the article
}

have had traditional therapies including TCM in daily life for many reasons [2, 3]. According to "WHO traditional medicine strategy: 2014-2023", over 100 million Europeans have tried traditional and complementary medicine products and healthcare services, one fifth of the consumers are reported to be regular users. The same phenomenon has also been found in Africa, Asia, Australia and North America with an estimated output of Chinese materia medica to be US\$83.1 billion in 2012 [4]. With such amount of consumption worldwide, problems associated with herbal drugs and TCM application have been increasingly reported. For example, a very early report showed that young women applied slimming regimen consisted of Stephania tetrandra and Magnolia officinalis resulted in renal fibrosis due to the misuse of Aristolochia fangchi as Stephania tetrandra [5, 6]. It was also reported that exposure to aristolochic acids and their derivatives in herbal drugs (such as Aristolochia manshuriensis)

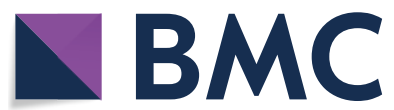

(c) The Author(s) 2020. This article is licensed under a Creative Commons Attribution 4.0 International License, which permits use, sharing, adaptation, distribution and reproduction in any medium or format, as long as you give appropriate credit to the original author(s) and the source, provide a link to the Creative Commons licence, and indicate if changes were made. The images or other third party material in this article are included in the article's Creative Commons licence, unless indicated otherwise in a credit line to the material. If material is not included in the article's Creative Commons licence and your intended use is not permitted by statutory regulation or exceeds the permitted use, you will need to obtain permission directly from the copyright holder. To view a copy of this licence, visit http://creativeco mmons.org/licenses/by/4.0/. The Creative Commons Public Domain Dedication waiver (http://creativecommons.org/publicdomain/ zero/1.0/) applies to the data made available in this article, unless otherwise stated in a credit line to the data. 
could give rise to kidney failure and hepatocellular carcinomas [7]. Medical incidents of herbal drugs treatments are highly related to the quality of herbal drugs, which might due to adulterants, contaminations (such as pesticides and heavy metals), and might also because of the wrong botanical parts used during treatment. Furthermore, incidents may also happen due to processing of herbal drugs, which may involve change in the content of active components and even transforming components in herbal drugs into toxic chemicals. In a recent market study conducted in UK, of the 211 samples investigated, 20 unofficial species were found and 17 samples were detected to have different degree of contamination with other impurities, including other plants, stones and earth etc. [8]. Thus, it is very important to monitor the quality of herbal drugs and TCM.

By realizing the above issue, the Chinese government started to establish the Chinese Pharmacopoeia (ChP) in 1950, and 65 medicaments from plant origins, oils and fats were included in the first edition of ChP (1953 edition). Then, in the second edition (1963 edition) of ChP, TCM was officially organized in Volume I and it was separated from chemical drugs since then. Through years of revisions, the 2020 edition of $\mathrm{ChP}$ is the 11th edition of ChP containing 2711 monographs of TCM. On the other hand, European Directorate for the Quality of Medicines \& Health Care (EDQM) has started to work on quality control monographs for herbal drugs in European Pharmacopoeia (EP) since 1997. But it was not until 2005, a working program for TCM had been started. The objective of the program is to construct TCM monographs in EP according to the EP's herbal drugs quality control principles. A special Working Party on TCM constituted by a group of experts and specialists from Europe been formed since 2008 and later on scientists from Asia also joined this working group, to work on a list of TCM candidates with a scheduled working progress $[9,10]$. The construction of TCM monographs in EP is on the basis of $\mathrm{ChP}$ following the principles, style and technical guideline of EP, with consideration of information in WHO monographs and Hong Kong Chinese Materia Medica Standard [10]. Up until EP10.2 (published in January, 2020), there are 73 herbal drugs considered as TCM in EP according to EP chapter " 5.22 . Names of herbal drugs used in traditional Chinese medicine", other herbal drugs such as Ginkgo leaf and St. John's wort are still considered to be European herbal drugs in EP because of their long history of application in Europe. Since the quality control systems of herbal drugs in Europe and China are different, monographs of TCM are different in the two pharmacopoeias as well. Additional file 1: Table S1 has compared the origin, identification markers, tests and assays of TCM and other European herbal drugs in both pharmacopoeias, differences are found in terms of the botanic origin, quality control markers and methods described in the two pharmacopoeias. Moreover, with more and more studies on TCM quality, new findings of sophisticated analytical techniques have been reported, which may be beneficial in constructing TCM quality control monographs.

Therefore the objectives of this review is to summarize and discuss the differences between the TCM monographs in EP 10th edition (data updated to supplement 10.2, published in January, 2020) and ChP 2020 edition to emphasize the state of TCM monographs in the EP. Note that TCM in this review refer to the 73 herbal drugs considered as TCM in both pharmacopoeias in order to avoid confusions, other examples out of the 73 TCM are given as herbal drugs in general. Furthermore, some advanced analytical techniques for quality standard of herbal drugs and TCM are also discussed to show the progress of TCM quality control.

\section{Comparison of TCM monographs between EP and ChP \\ Origins}

Herbal drugs and most of TCM materia medica are derived from plants, thus the origin of TCM usually consist of their botanical sources and medicinal parts. In both pharmacopoeias, origin of the herbal drugs including botanical sources, medicinal parts and their status is specifically stated in the "Definition" section (EP) or at the beginning of each monograph (ChP). A comparison of TCM with different botanical sources and/ or medicinal parts is summarized in Table 1. From the table, the most apparent difference is the frequent inclusion of multi-species and/or subspecies for one TCM in ChP. Although EP might also include several botanical origins for one TCM, such as Akebiae Caulis, Coptidis Rhizoma and Piperis Longi Fructus, such cases are not found as frequently as those in ChP. Inclusion of multiple species could be dated back in ancient practice of TCM for many reasons, which may due to different practice between regions and doctors, plant distribution between places, substitution of one species to another, or revision in prescription over time etc. However, significant differences in the chemical profiles may exist between different species of TCM, posing possible quality issues in TCM application. For example, there are three botanical sources of Coptidis Rhizoma stated in both EP and ChP: Coptis chinensis, Coptis deltoidea and Coptis teeta. It was shown that the three species had significant differences in their phytochemical profile, particularly with regard to the pharmacologically active alkaloids [11-13]. Another example is Uncariae Ramulus cum Uncis, EP states that its botanical source is Uncaria rhynchophylla, but there 


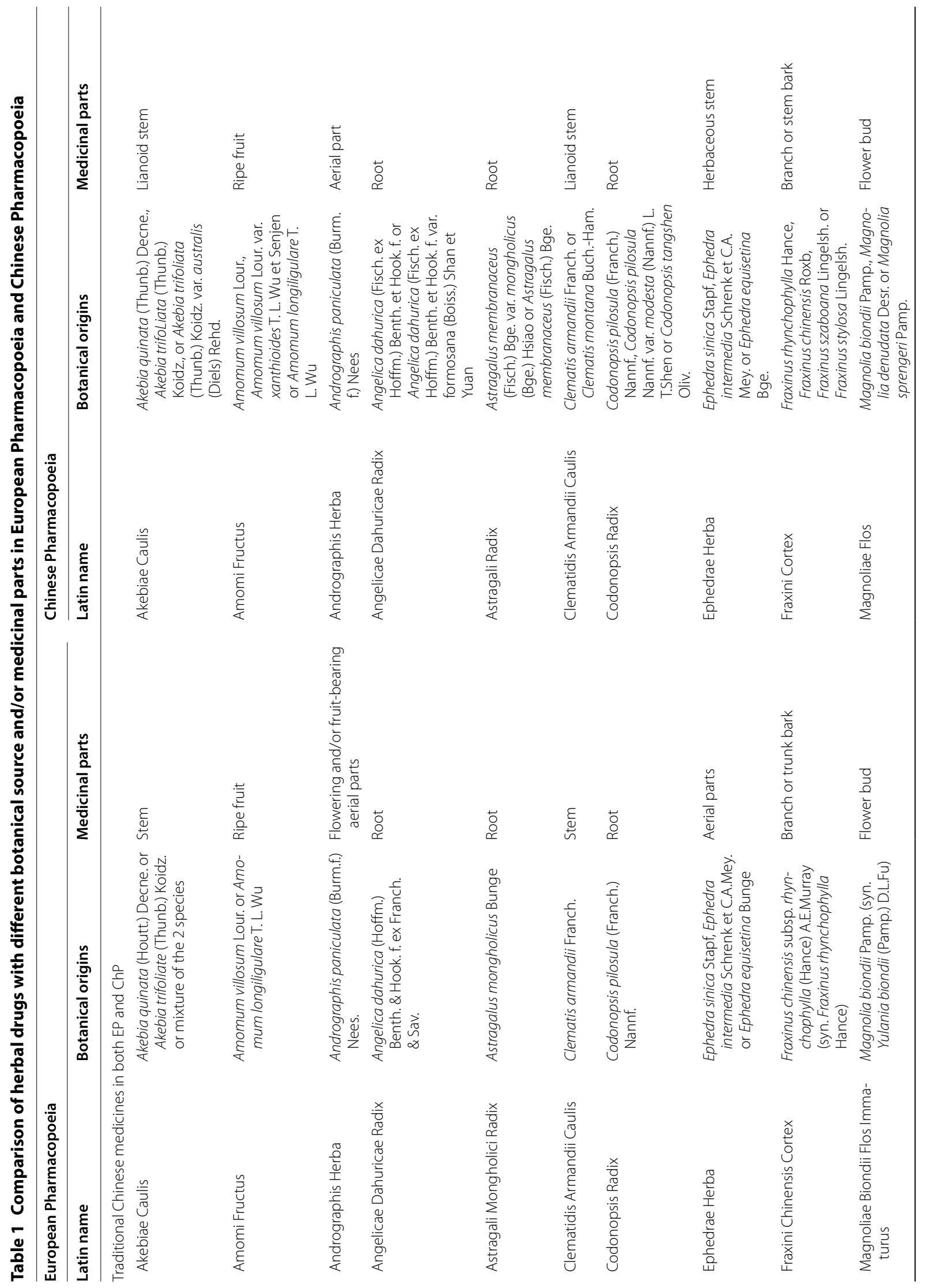




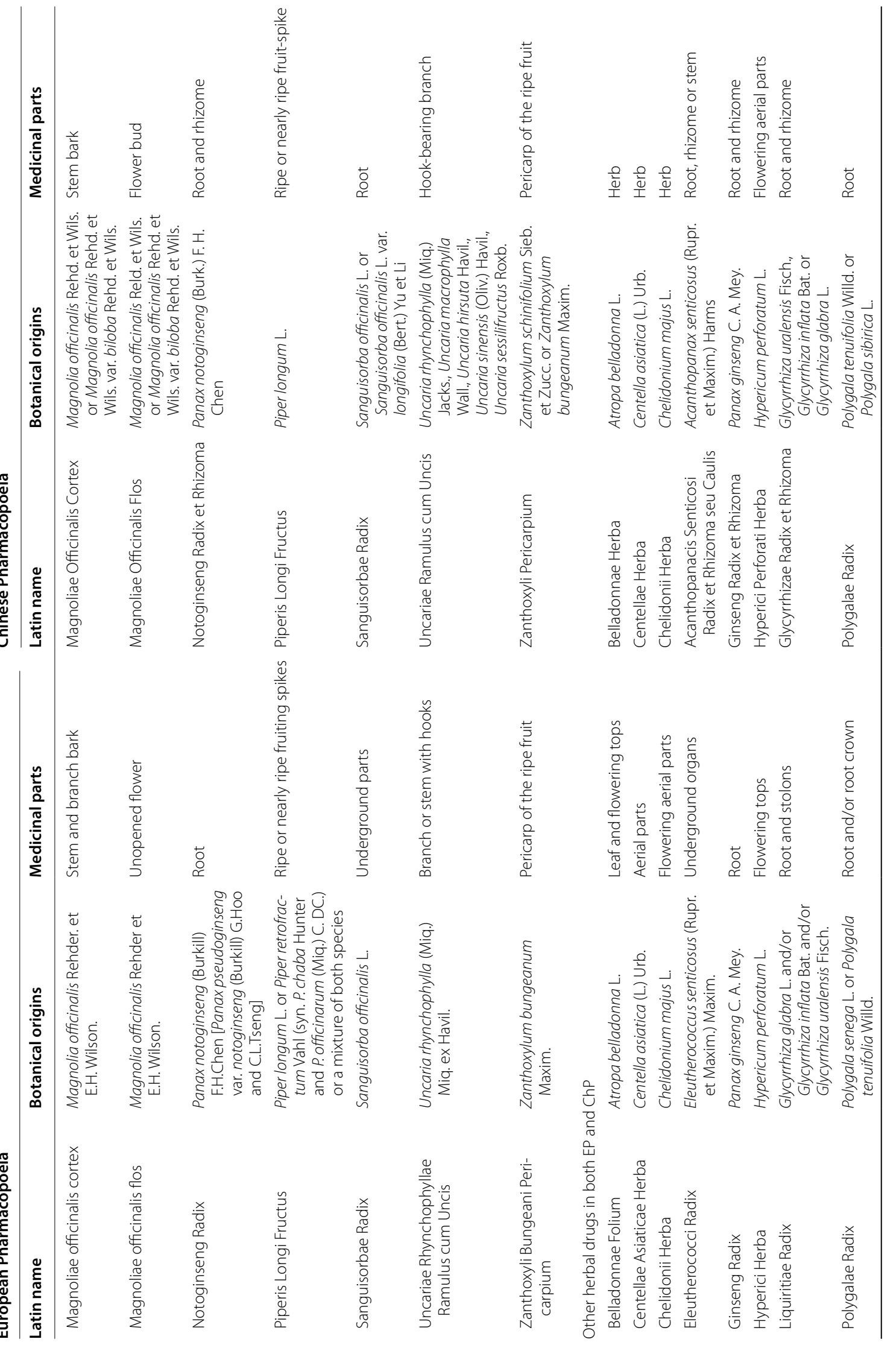




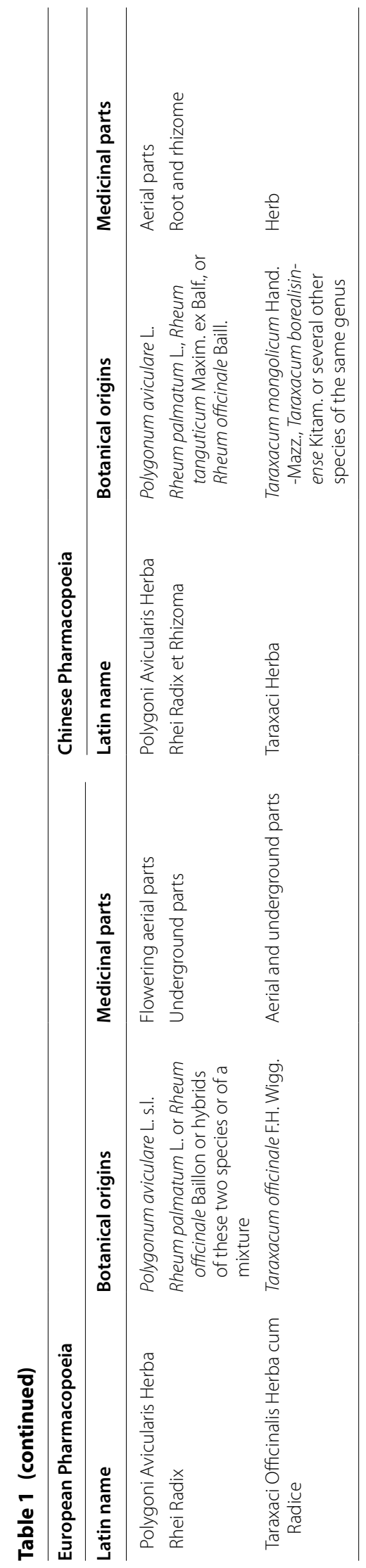


are five botanical sources in ChP: Uncaria rhynchophylla, Uncaria macrophylla, Uncaria hirsute, Uncaria sinensis and Uncaria sessilifructus. The genetic analysis based on rDNA ITS sequences showed that Uncaria rhynchophylla, Uncaria sinensis and Uncaria hirsute were closely related to each other but were far away from Uncaria macrophylla and Uncaria sessilifructus [14]. The chromatographic fingerprint showed that significant difference could be observed among the five Uncaria species, yet there were also some similarities between each other [14, 15]. As mentioned above, there are reasons to include several species and subspecies for one TCM in the monographs, but it brings more difficulty and challenges for the quality control and pharmacological study.

In addition, Latin synonyms in pharmacopoeias could be an issue for identification of botanical origins of TCM. An analysis showed that at least $16.13 \%$ Latin names of TCM in ChP (2010 edition) were not in accordance with Flora of China and the reasons of the issue may include: repeat naming of the same species; synonyms of the families; new definitions of species and families; as well as traditional use of old Latin names [16]. Among the 73 TCM reviewed, 24 entries have Latin synonyms stated in EP, and some other TCM without annotation may also have Latin synonyms. For example, botanical origins of Sinomenii Caulis in ChP include Sinomenium acutum (Thunb.) Rehd. et Wils. or Sinomenium acutum (Thunb.) Rehd. et Wils. var. cinereum Rehd. et Wils. But in fact, the latter is synonym of the former, and the former is the botanical origin stated in EP, thus the botanical origin of Sinomenii Caulis in both pharmacopoeias is actually the same. Therefore, when determining the botanical origins of TCM, Latin synonyms is still an issue that should be addressed.

In the application of TCM, herbs could be applied either as in whole plant, or as in different parts of the plant such as aerial parts, underground parts, root, rhizome, stem, bark, leaf or flower. Furthermore, active constituents and harmful constituents may be varied in different parts of an herb. Therefore, it is very important to specify the medicinal parts in quality standard of TCM. By comparing the stated medicinal parts of TCM between the two pharmacopoeias, most are the same except few such as Ephedrae Herba and Sanguisorbae Radix (Table 1). But the differences in these TCM are small, such as underground parts instead of root, thus little or no influence would be generated under the circumstances.

The above examples imply that it is important to specify the botanical source and the medicinal part of a TCM, because substantial differences may occur in the components and pharmacological effects when the wrong plant or medicinal parts are applied. However, the origin of herbal drugs and TCM stated in pharmacopoeias may be more or less influenced by the species available and the application habit in the region. Therefore, extensive research are required to show that if those differences could be compatible with each other and whether substitution is possible for one to another.

\section{Identification}

TCM identification in EP and ChP have many similarities, but they also have several significant differences in terms of method and marker selections. For a typical TCM monograph, identification includes: macroscopic examination of the herbal drug's botanical characteristics such as their shape, color or surface texture; microscopic examination of the powder for microstructure inspection of the herbal drug's tissues and cells; and thin layer chromatography (TLC) for chemical-based identification. All the tests are important in TCM identification because macroscopic and microscopic examination are more convenient for community pharmacies and consumers to easily identify TCM with less sophisticated equipment, and TLC identification is a more accurate and precise method to identify TCM in a more equipped laboratory. Whether to use some of the above tests or all of them depends on whether the method is feasible or has significant meaning in TCM identification, also special identification tests may sometimes be needed for further identification of the TCM from other similar herbs. In EP, TLC analysis of a TCM may be used as both identification and controlling adulterants in the monograph, the method under this situation is described in "Tests" and the method would be cross-referred to "Identiication". For example, Angelicae Dahuricae Radix, Angelicae Pubescentis Radix and Angelicae Sinensis Radix all incorporate a TLC test to differentiate the TCM with other officinal species of Angelica, Levisticum and Ligusticum, the method is also utilized as TLC identification for these three TCM.

In both pharmacopoeias, TLC is the most important identification method for TCM, because many herbal drugs share very similar features and it is often very hard to distinguish one from another by macroscopic and microscopic identification. Also, TLC is a relatively simple and convenient method for accurate, precise and easily interpreted identification of TCM, compared to techniques such as high performance liquid chromatography (HPLC) and gas chromatography (GC). The general procedures of TLC identification in both pharmacopoeias are the same, but EP and ChP employ different styles to illustrate TLC results. TLC results of EP are usually presented as a schematic box showing the positions of the bands. On the other hand, TLC results of $\mathrm{ChP}$ are presented as a simple description: "The spot in 
the chromatogram obtained with the test solution corresponds in position and colour to the spot in the chromatogram obtained with the reference solution". In addition, EP and ChP may use quite different TLC method for TCM identification based on the selected marker. For example, TLC identification method for Belamcandae Rhizoma including solid phase (EP: silica gel plate; ChP: polyamide film), mobile phase (EP: glacial acetic acid, cyclohexane and ethyl acetate in 1:20:80; ChP: chloroform, butanone and methanol in 3:1:1) and detection (EP: $254 \mathrm{~nm}$; ChP: $365 \mathrm{~nm}$ after visualization with aluminium trichloride solution) are different between EP and ChP, mainly because of the different marker used (EP: irisflorentin and coumarin; ChP: Belamcandae Rhizoma reference drug).

\section{Test}

In both pharmacopoeias, different tests are required to detect different contaminations and adulterants according to the nature of each TCM. EP has a general monograph named "Herbal drugs" and required tests are listed in the monograph, including foreign matter, loss on drying, water, pesticides, heavy metals, total ash, ash insoluble in hydrochloric acid, extractable matter, swelling index, bitterness value, aflatoxin $\mathrm{B}_{1}$, ochratoxin $\mathrm{A}$, radioactive contamination and microbial contamination. Each test is cross-referred to other chapters of EP which specify the analytical methods. General requirements of foreign matter and heavy metals are included in this general monograph, and general limits of pesticides and aflatoxin $\mathrm{B}_{1}$, are given in the monographs of corresponding analytical methods. ChP also has a general chapter entitled "0212 General principle for inspection of crude drugs and decoction pieces" requiring the tests for the content of water, ash, foreign matters, poisonous ingredients, heavy metals, harmful elements, pesticides residues, aflatoxins, etc., and gives the general limits of the content of water, foreign matter, sulfur dioxide and pesticides. The relevant methods are provided in a series of general chapters under the catalogue "2000 Special methods for traditional Chinese medicines". Besides the above differences in the general monograph, some other differences are also found when comparing the "Tests" section in TCM monographs between EP and ChP, which should be taken into consideration in quality control of TCM.

In quality assessment of TCM, moisture content is an important issue because inappropriate moisture would facilitate microbes' growth, resulting in decomposition or toxin generation in TCM. Therefore "Loss on drying" or "Water" is often required in the monograph to determine TCM's moisture content. However, even though "Water" and "Loss on drying" seem to be very similar, they are different not only in their method, but also what they convey in the monographs. "Loss on drying" determines the weight loss of TCM during specific condition such as heating or vacuum, which may include water and volatile contents in TCM, while "Water" determines only the moisture in TCM. Usually, the result of "Loss on drying" and "Water" will be the same for TCM with no or little volatile substances. But significant difference in the results may happen when applying different methods to determine the TCM containing high volatile content [17, 18]. A comparison of the methods for moisture determination in the two pharmacopoeias is summarized in Table 2. There is only little difference between the methods of "Loss on drying", but major differences could be found in "Water". EP has only included toluene distillation in the method, but ChP has also included Karl-Fischer

\section{Table 2 Summary of the methods for determination of "loss on drying" and "water" in European Pharmacopoeia and Chinese Pharmacopoeia}

\begin{tabular}{|c|c|}
\hline European Pharmacopoeia & Chinese Pharmacopoeia \\
\hline \multicolumn{2}{|l|}{ Loss on drying } \\
\hline $\begin{array}{l}\text { Dry the sample under the specified temperature to constant mass } \\
\left(\Delta \mathrm{m}^{\mathrm{a}} \leq 0.5 \mathrm{mg}\right) \text { or for the prescribed time by one of the following pro- } \\
\text { cedures and calculate the difference in the mass of the sample before } \\
\text { and after drying, expressed as a percentage }(\mathrm{m} / \mathrm{m}) \text { : } \\
\text { In a desiccator } \\
\text { In vacuo } \\
\text { In an oven at a specified temperature }\end{array}$ & $\begin{array}{l}\text { Place about } 1 \mathrm{~g} \text { or specified amount of sample in a tared, shallow weigh- } \\
\text { ing bottle and dry the sample under } 105^{\circ} \mathrm{C} \text { until constant weight } \\
(\Delta \mathrm{m} \leq 0.3 \mathrm{mg} \text { ) except as otherwise herein provided. Calculate the loss of } \\
\text { mass expressed as per cent } \\
\text { Test may also be done with desiccator with temperature control or vacuum }\end{array}$ \\
\hline \multicolumn{2}{|l|}{ Water } \\
\hline $\begin{array}{l}\text { Distillation with toluene (procedure similar to method } 4 \text { in Chinese } \\
\text { Pharmacopoeia) }\end{array}$ & $\begin{array}{l}\text { Method 1: Karl-Fischer's titration } \\
\text { Method 2: Drying in the oven }\left(100-105^{\circ} \mathrm{C} \text { until } \triangle \mathrm{m} \leq 5 \mathrm{mg}\right) \\
\text { Method 3: Drying under reduced pressure }(\leq 2.67 \mathrm{kPa} \text { at room temperature } \\
\text { for } 24 \mathrm{~h}) \\
\text { Method 4: Toluene distillation } \\
\text { Method 5: Gas chromatography }\end{array}$ \\
\hline
\end{tabular}

\footnotetext{
a $\Delta \mathrm{m}$ : the difference in the mass of the sample between two consecutive weighings
} 
titration, drying in oven, drying under reduced pressure and GC as well. When comparing the frequency of different methods for TCM moisture determination, drying in oven method is the most applied. Among the 73 TCM reviewed, 66 in EP and 51 in ChP employ this method. Furthermore, 7 TCM monographs in EP and 13 in ChP use toluene distillation method, mainly based on the volatile content of the TCM, since EP states that toluene distillation method instead of drying in oven or in vacuo should be carried out for herbal drugs with high essential oil content, ChP also states that drying in oven method should be used for crude drugs with little or no volatile constituents. Table 3 shows the differences in the methods between the two pharmacopoeias with the TCM's essential oil contents for reference. A typical example would be Atractylodis Macrocephalae Rhizoma, limit for "Water" in EP and ChP are $10 \%(100 \mathrm{~mL} / \mathrm{kg})$ and $15 \%$, respectively. The significant difference in the standard may mainly due to the difference in the methods, because the essential oil content of Atractylodis Macrocephalae Rhizoma should be no less than $9 \mathrm{~mL} / \mathrm{kg}$ according to EP. Furthermore, parameters of the methods applied in pharmacopoeias may also have impact on the result. EP specifies drying process to be $105{ }^{\circ} \mathrm{C}$ usually for certain hours, while $\mathrm{ChP}$ requires the sample to be dried until the difference between two successive weighings is not more than $5 \mathrm{mg}$, thus residual in moisture may affect the result and standard of certain TCM, such as Bupleuri Radix (EP: 5\%; ChP: 10\%), Isatidis Radix (EP: 9\%; ChP: 15\%) and Schisandrae Chinensis Fructus (EP: 10\%; ChP: 16\%) (Additional file 1: Table S1). Therefore, consideration should be taken when using either "Loss on drying" or "Water" for a specific TCM, because different results may be obtained when using different methods to determine the moisture content in TCM.

Pesticides are substances used to prevent, destroy or control pest, unwanted plants or animals during the production of herbal drugs. Pesticides may remain in the TCM if inappropriate approach is conducted during production, which will become pesticides residues and could be potential toxins to consumers. Therefore, EP requires pesticide residue test for herbal drugs and it is cross-referred to chapter "2.8.13 Pesticides residues". A list consisted of 69 pesticides' limits is included in the chapter, limits of other pesticides are cross-referred to Regulation (EC) No. 396/2005 or calculated by acceptable daily intake amount, body weight and daily dose of the herbal drug. Although there is no specification on the methods, analysis must be validated according to the requirements stated in chapter 2.8.13. In ChP, general chapter "2341 Determination of pesticide residues" specifies GC, GC-mass spectrometry (MS) or LC-MS techniques to determine the pesticide residues in TCM.
The chapter includes several categories of pesticides to be determined (organochlorine, organophosphorous, pyrethrin, etc.) and each has a detail description of determination method and a list of pesticides and their retention time, limit of detection etc. as guidance for quality control performers. The limits of 33 pesticides are given in the general chapter " 0212 General principle for inspection of crude drugs and decoction pieces", and special requirements are included for some herbal drugs, such as Astragali Radix, Ginseng Radix et Rhizoma and Glycyrrhizae Radix et Rhizoma (Additional file 1: Table S1).

Heavy metals may accumulate in TCM during production, causing symptoms such as anaemia, pains or organ failure to TCM users, thus heavy metals content should be strictly controlled in TCM [19]. EP chapter "2.4.27 Heavy metals in herbal drugs and herbal drug preparation" has included determination methods for arsenic, cadmium, copper, mercury, nickel and lead. The limits for herbal drugs in EP are as follow: cadmium $(\leq 1.0 \mathrm{ppm})$, lead $(\leq 5.0 \mathrm{ppm})$, mercury $(\leq 0.1 \mathrm{ppm})$, but special requirements may be needed for some herbal drugs such as Lini Semen (cadmium $\leq 0.5 \mathrm{ppm}$ ). As for ChP, "Heavy metals and harmful elements" are required only in some monographs (Angelicae Dahuricae Radix, Angelicae Sinensis Radix, Astragali Radix, Gardeniae Fructus, Lycii Fructus, Notoginseng Radix et Rhizoma, Paeoniae Radix Alba, Puerariae Lobatae Radix, Salviae Miltiorrhizae Radix et Rhizoma, etc.) and cross-referred to general chapter "2321 Determination of lead, cadmium, arsenic, mercury and copper", with limit of each element stated in each monograph (usually as follow: lead $\leq 5 \mathrm{mg} / \mathrm{kg}$, cadmium $\leq 1 \mathrm{mg} / \mathrm{kg}$, arsenic $\leq 2 \mathrm{mg} / \mathrm{kg}$, mercury $\leq 0.2 \mathrm{mg} /$ $\mathrm{kg}$, copper $\leq 20 \mathrm{mg} / \mathrm{kg}$ ). Atomic absorption spectrometry and inductively coupled plasma (ICP)-MS are introduced in this general chapter as the determination methods of heavy metals content in TCM, which are the mostly applied methods in heavy metal determination nowadays [20]. In addition, different forms or species of heavy metals determine their properties and especially toxicity. For example, the $\mathrm{LD}_{50}$ values of different arsenic species in rat are different, the most toxic species would be arsine with $\mathrm{LD}_{50}$ of $3.0 \mathrm{mg} / \mathrm{kg}$, but monomethylarsonic acid and dimethylarsinic acid would be considered "non-toxic" with $\mathrm{LD}_{50}$ between 700 and $2600 \mathrm{mg} / \mathrm{kg}$ [21]. In TCM, heavy metals could also present in the herb in many forms, especially for arsenic and mercury [22-24]. Therefore, it is important to identify the forms of heavy metals in TCM to rationally assess the potential hazard of inorganic impurities in TCM. ChP general chapter "2322 Determination of mercury and arsenic speciation and their valence states" has specified HPLC-ICP-MS to determine the species of arsenic and mercury in TCM. The method is now the most applied method in heavy 
Table 3 Comparison of herbal drugs with different methods for "loss on drying" or "water" content and their essential oil contents in European Pharmacopoeia and Chinese Pharmacopoeia

\begin{tabular}{|c|c|c|c|c|c|c|c|}
\hline \multicolumn{4}{|c|}{ European Pharmacopoeia } & \multicolumn{4}{|c|}{ Chinese Pharmacopoeia } \\
\hline Latin name & Methods & Limits & $\begin{array}{l}\text { Contents } \\
\text { of essential oil }\end{array}$ & Latin name & Methods & Limits & $\begin{array}{l}\text { Contents } \\
\text { of essential oil }\end{array}$ \\
\hline \multicolumn{8}{|c|}{ Traditional Chinese medicines in both EP and ChP } \\
\hline $\begin{array}{l}\text { Andrographis } \\
\text { Herba }\end{array}$ & $\operatorname{LD}\left(105^{\circ} \mathrm{C}, 2 \mathrm{~h}\right)$ & $\leq 10.0 \%$ & Not included & $\begin{array}{l}\text { Andrographis } \\
\text { Herba }\end{array}$ & Not included & Not included & Not included \\
\hline $\begin{array}{l}\text { Angelicae Dahu- } \\
\text { ricae Radix }\end{array}$ & $\operatorname{LD}\left(105^{\circ} \mathrm{C}, 2 \mathrm{~h}\right)$ & $\leq 12.0 \%$ & Not included & $\begin{array}{l}\text { Angelicae Dahuri- } \\
\text { cae Radix }\end{array}$ & $\begin{array}{l}\text { Water (toluene } \\
\text { distillation) }\end{array}$ & $\leq 14.0 \%$ & Not included \\
\hline $\begin{array}{l}\text { Angelicae } \\
\text { Pubescentis } \\
\text { Radix }\end{array}$ & $\operatorname{LD}\left(105^{\circ} \mathrm{C}, 2 \mathrm{~h}\right)$ & $\leq 10.0 \%$ & Not included & $\begin{array}{l}\text { Angelicae } \\
\text { Pubescentis } \\
\text { Radix }\end{array}$ & $\begin{array}{l}\text { Water (toluene } \\
\text { distillation) }\end{array}$ & $\leq 10.0 \%$ & Not included \\
\hline $\begin{array}{l}\text { Angelicae Sinen- } \\
\text { sis Radix }\end{array}$ & $\operatorname{LD}\left(105^{\circ} \mathrm{C}, 2 \mathrm{~h}\right)$ & $\leq 12.0 \%$ & Not included & $\begin{array}{l}\text { Angelicae Sinensis } \\
\text { Radix }\end{array}$ & $\begin{array}{l}\text { Water (toluene } \\
\text { distillation) }\end{array}$ & $\leq 15.0 \%$ & $\geq 0.4 \%$ \\
\hline $\begin{array}{l}\text { Atractylodis } \\
\text { Macrocephalae } \\
\text { Rhizoma }\end{array}$ & $\begin{array}{l}\text { Water (toluene } \\
\text { distillation) }\end{array}$ & $\leq 100 \mathrm{~mL} / \mathrm{kg}$ & $\geq 9 \mathrm{~mL} / \mathrm{kg}$ & $\begin{array}{l}\text { Atractylodis } \\
\text { Macrocephalae } \\
\text { Rhizoma }\end{array}$ & $\begin{array}{l}\text { Water (100- } \\
\begin{array}{l}105^{\circ} \mathrm{C} \text { until } \\
\left.\Delta \mathrm{m}^{\mathrm{a}} \leq 5 \mathrm{mg}\right)\end{array}\end{array}$ & $\leq 15.0 \%$ & Not included \\
\hline $\begin{array}{l}\text { Aucklandiae } \\
\text { Radix }\end{array}$ & $\operatorname{LD}\left(105^{\circ} \mathrm{C}, 2 \mathrm{~h}\right)$ & $\leq 12.0 \%$ & Not included & Aucklandiae Radix & Not included & Not included & Not included \\
\hline $\begin{array}{l}\text { Citri Reticulatae } \\
\text { Epicarpium et } \\
\text { Mesocarpium }\end{array}$ & $\operatorname{LD}\left(105^{\circ} \mathrm{C}, 2 \mathrm{~h}\right)$ & $\leq 12.0 \%$ & Not included & $\begin{array}{l}\text { Citri Reticulatae } \\
\text { Pericarpium }\end{array}$ & $\begin{array}{l}\text { Water (toluene } \\
\text { distillation) }\end{array}$ & $\leq 13.0 \%$ & Not included \\
\hline $\begin{array}{l}\text { Eucommiae } \\
\text { Cortex }\end{array}$ & $\operatorname{LD}\left(105^{\circ} \mathrm{C}\right)$ & $\leq 12.0 \%$ & Not included & $\begin{array}{l}\text { Eucommiae } \\
\text { Cortex }\end{array}$ & Not included & Not included & Not included \\
\hline $\begin{array}{l}\text { Ligustici Chuanx- } \\
\text { iong Rhizoma }\end{array}$ & $\operatorname{LD}\left(105^{\circ} \mathrm{C}, 2 \mathrm{~h}\right)$ & $\leq 8.0 \%$ & $\geq 3.5 \mathrm{~mL} / \mathrm{kg}$ & $\begin{array}{l}\text { Chuanxiong } \\
\text { Rhizoma }\end{array}$ & $\begin{array}{l}\text { Water (toluene } \\
\text { distillation) }\end{array}$ & $\leq 12.0 \%$ & Not included \\
\hline $\begin{array}{l}\text { Ligustici Radix et } \\
\text { Rhizoma }\end{array}$ & $\operatorname{LD}\left(105^{\circ} \mathrm{C}\right)$ & $\leq 12.0 \%$ & $\geq 5.0 \mathrm{~mL} / \mathrm{kg}$ & $\begin{array}{l}\text { Ligustici Rhizoma } \\
\text { et Radix }\end{array}$ & $\begin{array}{l}\text { Water (toluene } \\
\text { distillation) }\end{array}$ & $\leq 10.0 \%$ & Not included \\
\hline Lycii Fructus & $\operatorname{LD}\left(105^{\circ} \mathrm{C}, 2 \mathrm{~h}\right)$ & $\leq 11.0 \%$ & Not included & Lycii Fructus & $\begin{array}{l}\text { Water }\left(80^{\circ} \mathrm{C} \text { until }\right. \\
\Delta \mathrm{m} \leq 5 \mathrm{mg})\end{array}$ & $\leq 13.0 \%$ & Not included \\
\hline $\begin{array}{l}\text { Magnoliae } \\
\text { Biondii Flos } \\
\text { Immaturus }\end{array}$ & $\begin{array}{l}\text { Water (toluene } \\
\text { distillation) }\end{array}$ & $\leq 100 \mathrm{~mL} / \mathrm{kg}$ & $\geq 14.0 \mathrm{~mL} / \mathrm{kg}$ & Magnoliae Flos & Water (GC) & $\leq 18.0 \%$ & $\geq 1.0 \%$ \\
\hline $\begin{array}{l}\text { Magnoliae Offici- } \\
\text { nalis Cortex }\end{array}$ & $\operatorname{LD}\left(105^{\circ} \mathrm{C}, 2 \mathrm{~h}\right)$ & $\leq 11.0 \%$ & Not included & $\begin{array}{l}\text { Magnoliae Offici- } \\
\text { nalis Cortex }\end{array}$ & $\begin{array}{l}\text { Water (toluene } \\
\text { distillation) }\end{array}$ & $\leq 15.0 \%$ & Not included \\
\hline $\begin{array}{l}\text { Magnoliae Offici- } \\
\text { nalis Flos }\end{array}$ & $\operatorname{LD}\left(105^{\circ} \mathrm{C}\right)$ & $\leq 11.0 \%$ & Not included & $\begin{array}{l}\text { Magnoliae Offici- } \\
\text { nalis Flos }\end{array}$ & $\begin{array}{l}\text { Water (reduced } \\
\text { pressure } \\
(\leq 2.67 \mathrm{kPa}) \text { at } \\
\text { room tempera- } \\
\text { ture for } 24 \mathrm{~h})\end{array}$ & $\leq 10.0 \%$ & Not included \\
\hline Moutan Cortex & $\operatorname{LD}\left(105^{\circ} \mathrm{C}, 2 \mathrm{~h}\right)$ & $\leq 11.0 \%$ & Not included & Moutan Cortex & $\begin{array}{l}\text { Water (toluene } \\
\text { distillation) }\end{array}$ & $\leq 13.0 \%$ & Not included \\
\hline $\begin{array}{l}\text { Paeoniae Radix } \\
\text { Rubra }\end{array}$ & $\operatorname{LD}\left(105^{\circ} \mathrm{C}, 2 \mathrm{~h}\right)$ & $\leq 12.0 \%$ & Not included & $\begin{array}{l}\text { Paeoniae Radix } \\
\text { Rubra }\end{array}$ & Not included & Not included & Not included \\
\hline $\begin{array}{l}\text { Persicariae Tinc- } \\
\text { toriae Folium }\end{array}$ & $\operatorname{LD}\left(105^{\circ} \mathrm{C}, 2 \mathrm{~h}\right)$ & $\leq 7.0 \%$ & Not included & $\begin{array}{l}\text { Polygoni Tinctorii } \\
\text { Folium }\end{array}$ & Not included & Not included & Not included \\
\hline $\begin{array}{l}\text { Piperis Longi } \\
\text { Fructus }\end{array}$ & $\operatorname{LD}\left(105^{\circ} \mathrm{C}, 2 \mathrm{~h}\right)$ & $\leq 11.0 \%$ & $\geq 6.0 \mathrm{~mL} / \mathrm{kg}$ & $\begin{array}{l}\text { Piperis Longi } \\
\text { Fructus }\end{array}$ & $\begin{array}{l}\text { Water (toluene } \\
\text { distillation) }\end{array}$ & $\leq 11.0 \%$ & Not included \\
\hline $\begin{array}{l}\text { Polygoni Orien- } \\
\text { talis Fructus }\end{array}$ & $\mathrm{LD}\left(105^{\circ} \mathrm{C}, 2 \mathrm{~h}\right)$ & $\leq 12.0 \%$ & Not included & $\begin{array}{l}\text { Polygoni Orientalis } \\
\text { Fructus }\end{array}$ & Not included & Not included & Not included \\
\hline $\begin{array}{l}\text { Zanthoxyli } \\
\text { Bungeani } \\
\text { Pericarpium }\end{array}$ & $\begin{array}{l}\text { Water (toluene } \\
\text { distillation) }\end{array}$ & $\leq 100 \mathrm{~mL} / \mathrm{kg}$ & $\geq 15 \mathrm{~mL} / \mathrm{kg}$ & $\begin{array}{l}\text { Zanthoxyli Peri- } \\
\text { carpium }\end{array}$ & Not included & Not included & $\geq 1.5 \%$ \\
\hline \multicolumn{8}{|c|}{ Other herbal drugs in both EP and ChP } \\
\hline $\begin{array}{l}\text { Allii Sativi Bulbi } \\
\text { Pulvis }\end{array}$ & $\operatorname{LD}\left(105^{\circ} \mathrm{C}\right)$ & $\leq 7.0 \%$ & Not included & Allii Sativi Bulbus & Not included & Not included & Not included \\
\hline $\begin{array}{l}\text { Anisi Stellati } \\
\text { Fructus }\end{array}$ & $\begin{array}{l}\text { Water (toluene } \\
\text { distillation) }\end{array}$ & $\leq 100 \mathrm{~mL} / \mathrm{kg}$ & $\geq 70 \mathrm{~mL} / \mathrm{kg}$ & $\begin{array}{l}\text { Anisi Stellati } \\
\text { Fructus }\end{array}$ & Not included & Not included & $\geq 4.0 \%$ \\
\hline
\end{tabular}


Table 3 (continued)

\begin{tabular}{|c|c|c|c|c|c|c|c|}
\hline \multicolumn{4}{|c|}{ European Pharmacopoeia } & \multicolumn{4}{|c|}{ Chinese Pharmacopoeia } \\
\hline Latin name & Methods & Limits & $\begin{array}{l}\text { Contents } \\
\text { of essential oil }\end{array}$ & Latin name & Methods & Limits & $\begin{array}{l}\text { Contents } \\
\text { of essential oil }\end{array}$ \\
\hline $\begin{array}{l}\text { Belladonnae } \\
\text { Folium }\end{array}$ & Not included & Not included & Not included & $\begin{array}{l}\text { Belladonnae } \\
\text { Herba }\end{array}$ & $\begin{array}{l}\text { Water (100- } \\
105^{\circ} \mathrm{C} \text { until } \\
\left.\Delta \mathrm{m}^{\mathrm{a}} \leq 5 \mathrm{mg}\right)\end{array}$ & $\leq 13.0 \%$ & Not included \\
\hline Capsici Fructus & $\operatorname{LD}\left(105^{\circ} \mathrm{C}, 2 \mathrm{~h}\right)$ & $\leq 11.0 \%$ & Not included & Capsici Fructus & Not included & Not included & Not included \\
\hline Caryophylli Flos & Not included & Not included & $\geq 150 \mathrm{~mL} / \mathrm{kg}$ & Caryophylli Flos & $\begin{array}{l}\text { Water (toluene } \\
\text { distillation) }\end{array}$ & $\leq 12.0 \%$ & Not included \\
\hline $\begin{array}{l}\text { Foeniculi Amari } \\
\text { Fructus }\end{array}$ & $\begin{array}{l}\text { Water (toluene } \\
\text { distillation) }\end{array}$ & $\leq 100 \mathrm{~mL} / \mathrm{kg}$ & $\geq 40 \mathrm{mg} / \mathrm{kg}$ & Foeniculi Fructus & Not included & Not included & $\geq 1.5 \%$ \\
\hline $\begin{array}{l}\text { Foeniculi Dulcis } \\
\text { Fructus }\end{array}$ & $\begin{array}{l}\text { Water (toluene } \\
\text { distillation) }\end{array}$ & $\leq 80 \mathrm{~mL} / \mathrm{kg}$ & $\geq 20 \mathrm{mg} / \mathrm{kg}$ & Foeniculi Fructus & Not included & Not included & $\geq 1.5 \%$ \\
\hline Lini Semen & $\operatorname{LD}\left(105^{\circ} \mathrm{C}, 2 \mathrm{~h}\right)$ & $\leq 8.0 \%$ & Not included & Lini Semen & Not included & Not included & Not included \\
\hline Myrrha & $\operatorname{LD}\left(105^{\circ} \mathrm{C}, 2 \mathrm{~h}\right)$ & $\leq 15.0 \%$ & Not included & Myrrha & Not included & Not included & $\begin{array}{l}\geq 4.0 \% \text { for natura } \\
\text { myrrh, } \geq 2.0 \% \\
\text { for colloidal } \\
\text { myrrh }\end{array}$ \\
\hline
\end{tabular}

$L D$ loss on drying

a $\Delta \mathrm{m}$ : the difference in the mass of the sample between two consecutive weighings

metal speciation and has been applied in different TCM for heavy metal speciation [25-27]. But still, heavy metal speciation is only required for Cinnabaris (mercuric sulfide) and Realgar (arsenic disulfide) in ChP. Therefore, further research is needed to generate more data and knowledge in this area in order to develop advanced and rational inorganic impurities regulations for TCM.

In TCM production, TCM may be fumigated with sulfur as post-harvest process. Sulfur fumigation could have beneficial effects on TCM including preservation and better appearance but it also generates problems such as sulfur dioxide and heavy metal residues and changes in the chemical profile in TCM [28]. Since sulfur fumigation is an effective, low cost and traditional processing method in TCM production, many TCM crude drugs may go through sulfur fumigation before going to the market, which may cause toxicity to consumers, decrease in TCM quality and give rise to counterfeiting in the market, therefore determination of sulfur dioxide residue is necessary in order to prevent irrational use of sulfur fumigation in TCM production. In comparison, sulfur dioxide residue is not required in $\mathrm{EP}$, but it is required in $\mathrm{ChP}$ that limit of sulfur dioxide residue generally do not exceed $150 \mathrm{mg} / \mathrm{kg}$ except mineral drugs, and $400 \mathrm{mg} / \mathrm{kg}$ for 10 particular TCM including Achyranthis Bidentatae Radix, Atractylodis Macrocephalae Rhizoma, Codonopsis Radix, Dioscoreae Rhizoma, Gastrodiae Rhizoma, Paeoniae Radix Alba and Puerariae Thomsonii Radix, etc. In terms of determination method, $\mathrm{ChP}$ general chapter "2331 Determination of residue of sulfur dioxide" employs acid-base titration, GC and ion chromatography to determine the sulfur dioxide residue in TCM, quality control conductor may choose the appropriate method to determine the sulfur dioxide residue in TCM.

When TCM is stored under suitable temperature and humidity conditions for microorganisms, fungi and molds may grow in TCM and generate a large group of secondary metabolic products called mycotoxins. Mycotoxins consist of many categories including aflatoxin, ochratoxin, zearalenone, etc. and have hazardous effects to human body such as hepatic cell and tissue injury, reproductive disorders and diarrhea etc. [29]. Thus, both $\mathrm{EP}$ and $\mathrm{ChP}$ have included tests to control the mycotoxins level for TCM. Generally, EP chapter "2.8.18 Determination of aflatoxin $B_{1}$ in herbal drugs" and "2.8.22 Determination of ochratoxin $\mathrm{A}$ in herbal drugs" require herbal drugs subjected to contamination by aflatoxins $B_{1}$ or ochratoxin A should be tested by a validated method, and give the limit of aflatoxin $B_{1}$ (aflatoxin $B_{1} \leq 2 \mu \mathrm{g} / \mathrm{kg}$, sum of $G_{2}, G_{1}, B_{2}$ and $B_{1} \leq 4 \mu \mathrm{g} / \mathrm{kg}$ ). Special limit for the two mycotoxins may be required if necessary (e.g. ochratoxin A in Liquiritiae Radix $\leq 20 \mu \mathrm{g} / \mathrm{kg}$ ). ChP also requires some herbal drugs to have their mycotoxin content determined, and of the herbal drugs reviewed, Citri Reticulatae Pericarpium, Coicis Semen, Corydalis Rhizoma and Polygalae Radix are required to test their aflatoxins (aflatoxin $B_{1} \leq 5 \mu \mathrm{g} / \mathrm{kg}$, sum of $G_{2}, G_{1}, B_{2}$ and $B_{1} \leq 10 \mu \mathrm{g} /$ $\mathrm{kg}$ ), Coicis Semen is required to test its zearalenone $(\leq 500 \mu \mathrm{g} / \mathrm{kg})$. For mycotoxins determination, EP applies LC-fluorescence detection to determine the levels of aflatoxins $\mathrm{B}_{1}$ and ochratoxin $\mathrm{A}$ in TCM, while in $\mathrm{ChP}$ general chapter "2351 Determination of mycotoxins", LC and/ 
or LC-MS are specified to determine the mycotoxins in TCM, including aflatoxins, ochratoxin A, zearalenone, deoxynivalenol, patulin, etc. Additionally, enzyme-linked immunosorbent assay can also be used for aflatoxins determination.

"Extractable matter" in EP or "Extractives" in ChP determines the content of substances in TCM extracts using different solvents such as water, ethanol and ether. However, instead of a requirement in "Test" section, "Extractives" in ChP is separated from "Test" as an individual item in the monographs. Furthermore, of the 73 TCM reviewed, EP only requires $5 \mathrm{TCM}$ to have their extractable matter determined (Acanthopanacis Gracilistyli Cortex, Codonopsis Radix, Dioscoreae Oppositifoliae Rhizoma, Lycii Fructus and Poria), all without assay requirements in the monographs; on the other hand, a total of $50 \mathrm{TCM}$ in ChP need to determine their content of extractives, while the majority of them also have assay quantification in their monographs. The reason of EP not to include extractable matter in certain monographs is because extractable matter determination is useful only to TCM without a component suitable for an assay or TCM used to produce a preparation with a dry residue [30]. The methods used to determine extractable matter or extractives in both pharmacopoeias are very similar: certain amount of TCM is extracted with specific solvent, then the filtrate is evaporated to dryness and the residue is weighed to calculate the percentage of the extracts. However, EP does not have a general chapter for extractable matter, and methods are included only in corresponding monographs with stated limits for particular TCM; ChP on the other hand includes general chapter "2201 Determination of extractives" and three types of extractives including water, ethanol and volatile ether are described.

\section{Assay}

Besides TCM identification and different quality tests, one of the most important quality indicators for TCM is the content of active components, which is assessed in "Assay" in both pharmacopoeias. But EP and ChP may apply different techniques to assess the active components of TCM, and sometimes "Assay" may be absent if feasible technique is not available. A comparison of the methods is listed in Table 4. The numbers of different analytical methods applied in "Assay" section for herbal drugs in both EP and ChP are shown in Fig. 1. It is shown that HPLC remains the most applied analytical method in TCM assay, followed by essential oil determination, ultraviolet-visible spectroscopy (UV-Vis) and GC. HPLC in TCM assay has many advantages, such as high separation efficiency, wide range of application, good reproducibility, accuracy and short analysis time. Thus, HPLC is the most preferred techniques in TCM assay. Among the 73 TCM reviewed, 57 in EP and 60 in ChP employ HPLC for "Assay". While for volatile components determination, GC possesses many advantages over LC and therefore is used more often in herbal drugs with high content of volatile compounds. For example, Amomi Fructus, Amomi Fructus Rotundus, Foeniculi Fructus and Anisi Stellati Fructus all include GC analysis for "Assay" in both pharmacopoeias. Besides LC and GC, UV-Vis is another quantification technique used to determine a specific group of components with high degree of conjugation or can be highly conjugated after derivatization. Among the "Assay" of the 73 TCM monographs, 6 in EP and 5 in ChP apply UV-Vis method to determine flavonoids, alkaloids, tannins, etc. in the herbal drugs, showing that although many active components determination has been done by LC and GC, UV-Vis spectroscopy is still useful in quality control of TCMs, especially for TCMs without applicable chromatographic analysis.

\section{Sample preparation}

Sample preparation is very important in quality control of TCM because it started at the very early stage of an analysis and it has great impact on the performance of an analysis including selectivity, sensitivity and accuracy [31]. In both pharmacopoeias, heating under reflux and ultrasonication are the most used methods to extract the desired components in TCM, sample pretreatment including solid phase extraction (SPE), liquid-liquid extraction, $\mathrm{pH}$ adjustment, precipitation and centrifugal separation may also be applied to eliminate undesired influence of impurities, transform components into detectable compounds and enhance the extraction efficiency of the target compounds. Since quality control standard requires the method to be sensitive, stable, accurate and considerably simple and convenient, advanced sample preparation techniques may benefit the improvements of quality standard of TCM.

\section{Marker}

In quality control of TCM, since the composition and pharmacological effects of TCM are usually very complicated, single component, multiple components or even the global chemical profile with many components may be utilized to assess the quality of a specific TCM. Chemical reference substance (CRS) and herbal reference substance (HRS) in EP or CRS, reference extract and reference crude drug in $\mathrm{ChP}$ could be used as reference standards for TCM identification and compound quantification. Therefore, choosing the appropriate marker is very important for accurate and valid quality assessment of TCM, especially when active markers are not available in analysis. By comparing the markers used in both 
Table 4 Comparison of herbal drugs with different methods for "Assay" in European Pharmacopoeia and Chinese Pharmacopoeia

\begin{tabular}{|c|c|c|c|c|c|}
\hline \multicolumn{3}{|l|}{ European Pharmacopoeia } & \multicolumn{3}{|l|}{ Chinese Pharmacopoeia } \\
\hline Latin Name & Method & Limit & Latin name & Method & Limit \\
\hline \multicolumn{6}{|c|}{ Traditional Chinese medicines in both EP and ChP } \\
\hline Angelicae Sinensis Radix & LC & trans-Ferulic acid ( $\geq 0.050 \%)$ & Angelicae Sinensis Radix & $\begin{array}{l}\text { SD } \\
\text { HPLC }\end{array}$ & $\begin{array}{l}\text { Essential oil }(\geq 0.4 \%) \\
\text { Ferulic acid }(\geq 0.050 \%)\end{array}$ \\
\hline $\begin{array}{l}\text { Atractylodis Lanceae } \\
\text { Rhizoma }\end{array}$ & SD & Essential oil ( $\geq 14$ mL/kg) & Atractylodis Rhizoma & HPLC & Atractylodin ( $\geq 0.30 \%)$ \\
\hline $\begin{array}{l}\text { Atractylodis Macroceph- } \\
\text { alae Rhizoma }\end{array}$ & SD & Essential oil ( $\geq 9$ mL/kg) & $\begin{array}{l}\text { Atractylodis Macrocephalae } \\
\text { Rhizoma }\end{array}$ & Not included & \\
\hline Bistortae Rhizoma & UV-Vis & $\begin{array}{l}\text { Tannins ( } \geq 3.0 \% \text {, expressed } \\
\text { as pyrogallol) }\end{array}$ & Bistortae Rhizoma & HPLC & Gallic acid $(\geq 0.12 \%)$ \\
\hline Carthami Flos & UV-Vis & $\begin{array}{l}\text { Total flavonoids ( } \geq 1.0 \% \\
\text { expressed as hyperoside) }\end{array}$ & Carthami Flos & HPLC & $\begin{array}{l}\text { Hydroxysafflor yellow A } \\
(\geq 1.0 \%), \text { kaempferol } \\
(\geq 0.050 \%)\end{array}$ \\
\hline Clematidis Armandii Caulis & LC & Oleanolic acid ( $\geq 0.30 \%)$ & Clematidis Armandii Caulis & Not included & \\
\hline Houttuyniae Herba & LC & Qquercitrin ( $\geq 0.10 \%)$ & Houttuyniae Herba & Not included & \\
\hline $\begin{array}{l}\text { Ligustici Chuanxiong } \\
\text { Rhizoma }\end{array}$ & SD & Essential oil ( $\geq 3.5$ mL/kg) & Chuanxiong Rhizoma & HPLC & Ferulic acid ( $\geq 0.10 \%)$ \\
\hline Ligustici Rhizoma et Radix & SD & Essential oil $(\geq 5.0 \mathrm{~mL} / \mathrm{kg})$ & Ligustici Rhizoma et Radix & HPLC & Ferulic acid ( $\geq 0.050 \%)$ \\
\hline Lycii Fructus & Not included & & Lycii Fructus & $\begin{array}{l}\text { UV-Vis } \\
\text { HPLC }\end{array}$ & $\begin{array}{l}\text { Polysaccharide ( } \geq 1.8 \%, \\
\text { expressed as glucose) } \\
\text { Betaine }(\geq 0.50 \%)\end{array}$ \\
\hline Lycopi Herba & LC & Rosmarinic acid ( $\geq 0.15 \%)$ & Lycopi Herba & Not included & \\
\hline Piperis Fructus & $\begin{array}{l}\text { SD } \\
\text { LC }\end{array}$ & $\begin{array}{l}\text { Essential oil }(\geq 25 \mathrm{~mL} / \mathrm{kg}) \\
\text { Piperine }(\geq 3.0 \%)\end{array}$ & Piperis Fructus & HPLC & Piperine $(\geq 3.3 \%)$ \\
\hline Piperis Longi Fructus & $\begin{array}{l}\text { SD } \\
\text { LC }\end{array}$ & $\begin{array}{l}\text { Essential oil }(\geq 6.0 \mathrm{~mL} / \mathrm{kg}) \\
\text { Piperine }(\geq 3.0 \%)\end{array}$ & Piperis Longi Fructus & HPLC & Piperine $(\geq 2.5 \%)$ \\
\hline Sanguisorbae Radix & UV-Vis & $\begin{array}{l}\text { Tannins ( } \geq 5.0 \% \text {, expressed } \\
\text { as pyrogallol) }\end{array}$ & Sanguisorbae Radix & $\begin{array}{l}\text { UV-Vis } \\
\text { HPLC }\end{array}$ & $\begin{array}{l}\text { Tanninoids ( } \geq 8.0 \% \text {, expressed } \\
\text { as gallic acid) } \\
\text { Gallic acid }(\geq 1.0 \%)\end{array}$ \\
\hline $\begin{array}{l}\text { Uncariae Rhynchophyllae } \\
\text { Ramulus cum Uncis }\end{array}$ & LC & $\begin{array}{l}\text { Total alkaloids ( } \geq 0.2 \% \text {, } \\
\text { expressed as isorhyncho- } \\
\text { phylline) }\end{array}$ & $\begin{array}{l}\text { Uncariae Ramulus cum } \\
\text { Uncis }\end{array}$ & Not included & \\
\hline \multicolumn{6}{|c|}{ Other herbal drugs in both EP and ChP } \\
\hline Aloe Barbadensis & UV-Vis & $\begin{array}{l}\text { Hydroxyanthracene deriva- } \\
\text { tives ( } \geq 28.0 \% \text {, expressed } \\
\text { as barbaloin) }\end{array}$ & Aloe & HPLC & Barbaloin ( $\geq 16.0 \%$ ) \\
\hline Aloe Capensis & UV-Vis & $\begin{array}{l}\text { Hydroxyanthracene deriva- } \\
\text { tives ( } \geq 18.0 \% \text {, expressed } \\
\text { as barbaloin) }\end{array}$ & Aloe & HPLC & Barbaloin ( $\geq 6.0 \%)$ \\
\hline Benzoe Tonkinensis & Titration & $\begin{array}{l}\text { Total acids ( } 35.0 \%-55.0 \%, \\
\text { expressed as benzoic acid) }\end{array}$ & Benzoinum & HPLC & $\begin{array}{l}\text { Total balsamic acid ( } \geq 27.0 \% \\
\text { expressed as benzoic acid) }\end{array}$ \\
\hline Caryophylli Flos & SD & Essential oil ( $\geq 150$ mL/kg) & Caryophylli Flos & GC & Eugenol $(\geq 11.0 \%)$ \\
\hline Chelidonii Herba & UV-Vis & $\begin{array}{l}\text { Total alkaloids ( } \geq 0.6 \% \\
\text { expressed as chelidonine) }\end{array}$ & Chelidonii Herba & HPLC & Chelerythrine ( $\geq 0.020 \%)$ \\
\hline $\begin{array}{l}\text { Curcumae Longae } \\
\text { Rhizoma }\end{array}$ & $\begin{array}{l}\text { SD } \\
\text { UV-Vis }\end{array}$ & $\begin{array}{l}\text { Essential oil ( } \geq 25 \mathrm{~mL} / \mathrm{kg}) \\
\text { Dicinnamoyl methane } \\
\text { derivatives ( } \geq 2.0 \% \\
\text { expressed as curcumin) }\end{array}$ & Curcumae Longae Rhizoma & $\begin{array}{l}\text { SD } \\
\text { HPLC }\end{array}$ & $\begin{array}{l}\text { Essential oil }(\geq 7.0 \%) \\
\text { Curcumin }(\geq 1.0 \%)\end{array}$ \\
\hline Hyperici Herba & UV-Vis & $\begin{array}{l}\text { Total hypericins ( } \geq 0.08 \% \text {, } \\
\text { expressed as hypericin) }\end{array}$ & Hyperici Perforati Herba & HPLC & Hyperoside ( $\geq 0.10 \%)$ \\
\hline Lini Semen & Not included & & Lini Semen & GC & $\begin{array}{l}\text { Sum of linoleic acid and } \\
\text { a-linolenic acid ( } \geq 13.0 \%)\end{array}$ \\
\hline Myrrha & Not included & & Myrrha & SD & $\begin{array}{l}\text { Essential oil ( } \geq 4.0 \% \text { for natura } \\
\text { myrrh, } \geq 2.0 \% \text { for colloidal } \\
\text { myrrh) }\end{array}$ \\
\hline
\end{tabular}


Table 4 (continued)

\begin{tabular}{|c|c|c|c|c|c|}
\hline \multicolumn{3}{|l|}{ European Pharmacopoeia } & \multicolumn{3}{|l|}{ Chinese Pharmacopoeia } \\
\hline Latin Name & Method & Limit & Latin name & Method & Limit \\
\hline Polygalae Radix & Not included & & Polygalae Radix & HPLC & $\begin{array}{l}\text { Tenuifolin ( } \geq 2.0 \%) \text {, polyg- } \\
\text { alaxanthone III }(\geq 0.15 \%) \text {, } \\
\text { 3,6'-disinapoyl sucrose } \\
(\geq 0.50 \%)\end{array}$ \\
\hline Polygoni Avicularis Herba & UV-Vis & $\begin{array}{l}\text { Flavonoids ( } \geq 0.30 \%, \\
\text { expressed as hyperoside) }\end{array}$ & Polygoni Avicularis Herba & HPLC & Myricitrin ( $\geq 0.030 \%)$ \\
\hline Rhei Radix & UV-Vis & $\begin{array}{l}\text { Hydroxyanthracene deriva- } \\
\text { tives }(\geq 2.2 \% \text {, expressed } \\
\text { as rhein) }\end{array}$ & Rhei Radix et Rhizoma & HPLC & $\begin{array}{l}\text { Total anthraquinone ( } \geq 1.5 \% \text {, } \\
\text { hydrolysis and expressed as } \\
\text { sum of aloe-emodin, rhein, } \\
\text { emodin, chrysophanol and } \\
\text { physcion), free anthraqui- } \\
\text { none: sum of aloe-emodin, } \\
\text { rhein, emodin, chrysopha- } \\
\text { nol and physcion ( } \geq 0.20 \%)\end{array}$ \\
\hline $\begin{array}{l}\text { Taraxaci Officinalis Herba } \\
\text { cum Radice }\end{array}$ & Not included & & Taraxaci Herba & HPLC & Cichoric acid ( $\geq 0.45 \%)$ \\
\hline $\begin{array}{l}\text { Trigonellae Foenugraeci } \\
\text { Semen }\end{array}$ & Not included & & Trigonellae Semen & HPLC & Trigonelline ( $\geq 0.45 \%)$ \\
\hline Zingiberis Rhizoma & SD & Essential oil ( $\geq 15$ mL/kg) & Zingiberis Rhizoma & $\begin{array}{l}\text { SD } \\
\text { HPLC }\end{array}$ & $\begin{array}{l}\text { Essential oil }(\geq 0.8 \%) \\
6 \text {-Gingerol }(\geq 0.60 \%)\end{array}$ \\
\hline
\end{tabular}

GC gas chromatography, HPLC high performance liquid chromatography, LC liquid chromatography, SD steam distillation, UV-Vis ultraviolet-visible spectroscopy

\section{Traditional Chinese medicines}

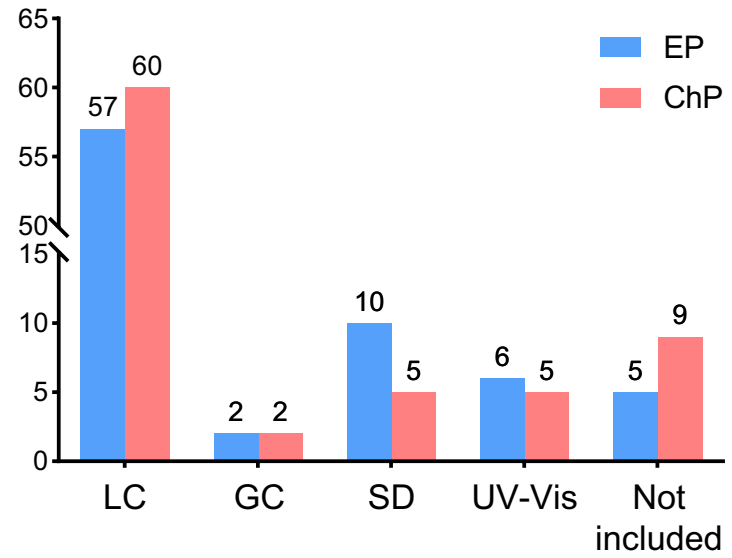

\section{Other herbal drugs}

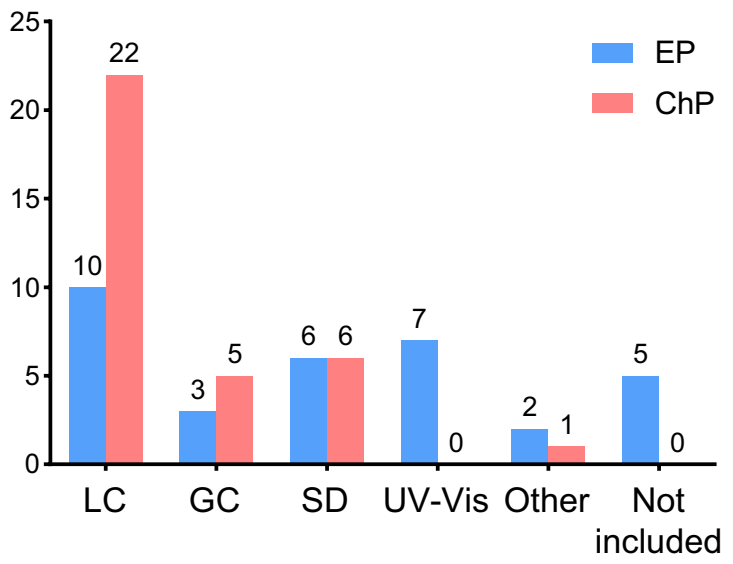

Fig. 1 Numbers of analytical methods applied in "Assay" section for herbal drugs recorded in both European Pharmacopoeia and Chinese Pharmacopoeia

pharmacopoeias, interesting differences are observed. Of the TCM reviewed, besides different choices of active markers in analysis, EP has included many analytical markers, which serve solely for analytical purposes and irrespective of any pharmacological or therapeutic activity, in TCM identification and quantification. For example, aescin and arbutin are used as analytical makers for TLC identification of Anemarrhenae Asphodeloides Rhizoma and Notoginseng Radix; caffeine is used as reference for the determination of pinoresinol diglucoside in Eucommiae Cortex. While ChP has included many reference crude drugs in TCM identification. Among the 73 TCM reviewed, 37 in ChP employ reference extract or reference drug in TCM identification, and 12 of them include only reference drug in monographs for TLC identification. In addition, EP has included many specific references for system suitability assessment, while $\mathrm{ChP}$ uses the intensity markers or active markers in 
TCM identification or assay for this purpose. For example, in EP, isoeugenol and methyleugenol are used for the system suitability test of TLC identification of Ophiopogonis Radix. Propyl parahydroxybenzoate and saikosaponin A are employed for the system suitability of LC quantification for Bupleuri Radix. Moreover, 20 out of 73 TCM apply HRS in system suitability assessment of LC assay. From the above, it is shown that other than active markers, analytical markers and HRS or reference drug are also applied in monographs either as substitution of active markers or for method validation and system suitability assessment etc., so they are important alternates when active markers are not available or with high costs.

\section{Prepared slices and TCM processing}

In clinical applications, TCM may be processed in some ways into prepared slices based on the theory of traditional Chinese medicine. TCM processing could be as simple as washing, cleaning, cutting and smashing, to more complicated procedures such as stir-frying, steaming and treating with honey, vinegar or wine, etc. [32]. In ChP, general chapter " 0213 The processing of crude drugs" specifies the relevant TCM processing methods. While for EP, although official monographs are not included, a draft general chapter "5.18 Methods of pretreatment for preparing traditional Chinese drugs: general information" has been published on Pharmaeuropa, an online EDQM publication providing public inquiries on draft EP texts. In addition, for TCM existed in both raw and processed form, ChP has included a section named "Prepared slices" at the end of the TCM monograph with the information of processing method and quality control tests, and/or a separate monograph of the processed TCM. For example, Polygoni Multiflori Radix has a separate monograph named "Polygoni Multiflori Radix Praeparata" included after the monograph of the raw drug. Not only the quality control requirements including water content, total ash, markers and their contents are different, the actions and indications are also different as well. Other examples include Astragali Radix and Rehmanniae Radix, etc. The inclusion of TCM processing in pharmacopoeia is very important because the processing of TCM can change the nature of drug, reduce toxicity, ensure safety and improve efficacy due to the change of constituents and content of active and/or toxic components before and after processing [32]. Also take Polygoni Multiflori Radix as an example, it was found that both raw and processed Polygoni Multiflori Radix exerted liver protection and toxicity, and the raw drug was more toxic than the processed drug. The hepatotoxicity may dominantly be attributed to the components of anthraquinones, and it was speculated that processing may alter the composition and contents of the toxicity related ingredients [33]. The above example demonstrates that TCM processing is a very important part in TCM application, however TCM processing may involve many different aspects in quality control such as excipients used in processing, products generated by processing and diversities in processing methods, thus more investigations should be carried out in processed TCM products.

\section{Comparison of other herbal drugs in EP and ChP}

For some herbal medicines other than the 73 TCM discussed above, even though they share the same botanical source between the pharmacopoeias, they are considered to be traditional European herbal drugs instead of TCM as mentioned at the beginning of this review. Those herbal drugs including Ginseng Radix, Liquiritiae Radix and Rhei Radix etc. has also been well known and frequently applied in herbal remedies of China. By comparing the monographs of these herbal drugs to TCM monographs, some similarities and differences are found. Although these herbal drugs may have at least one identical botanical source in the two pharmacopoeias, inclusion of other species into the monographs are also frequently happened in ChP and sometimes in EP. Also, although the medicinal parts stated in the monographs are similar, small differences (e.g. aerial parts instead of whole plant) may be occurred. The general requirements of these herbal drugs are similar to TCM, but quality control methods may be significantly different between the two pharmacopoeias since the monographs of these herbal drugs are not drafted by Working Party on TCM, and are not on the basis of ChP. For example, for Rhei Radix, there is a chemical identification test included in EP, which is not included in ChP; while for Aloe, the chemical identification method is included in ChP but not in EP. Furthermore, different assay methods may be applied for these herbal drugs including Aloes, Caryophylli Flos, Lini Semen, Rhei Radix, etc. (Table 4 and Fig. 1). The differences in the monographs of these herbal medicines between the two pharmacopoeias may be mainly originated from the different applications and indications between Europe and China. For example, according to European Medicines Agency, Curcumae Longae Rhizoma in Europe is mainly used for gastrointestinal disorders such as feelings of fullness, slow digestion and flatulence, but in ChP it is used for the relief of pain. The above illustration implies that, quality control of herbal drugs is relevant not only to the chemical compositions but also the application habits in the region. Therefore, it is important that quality control should meet the 
actual application of herbal drugs in daily life in order to protect the benefits and safety of consumers.

\section{Advanced analytical techniques for quality standard of TCM}

As shown previously, quality standard of TCM consists of origins, identification, test and assay, etc. Establishment of TCM quality standard usually include selection of quality markers, development of analytical methods, validation of the method, analysis of sufficient batches of samples and finally setting the limit requirement. In general, quality control of TCM or herbal drugs is more complicated than chemical drugs because of their complexity and different aspects in quality control. Therefore, advancement in quality control techniques is very important for TCM in order to provide valid quality control methods. With years of study, many advanced technologies have been applied in quality control of herbal drugs and some of them are proved to be effective in improving the quality control methods.

\section{Sample preparation techniques}

Sample preparation is very important in quality control of TCM because active components in TCM is complicated and usually in a very low content. In order to enhance the extraction efficiency, eliminate matrix effects and/or reduce consumption of organic solvents, modern extraction techniques such as microwave-assisted extraction, pressurized liquid extraction (PLE) and supercritical fluid extraction have been widely used for TCM. And online coupling of sample preparation with chromatographic techniques have gained increasing attention in recent years [34]. For example, an online-SPE hyphenated with polarity switching ultra-high performance LC (UHPLC)-MS/MS method was developed for the simultaneous determination of 10 aconite alkaloids and 13 ginsenosides in Shenfu injection. The validated method had advantages of high automatic, solvent-saving, and efficiency, can be adopted as a meaningful tool for the analysis of constituents in complex matrices without tedious sample preparation procedures [35]. Another online sample preparation system was configured by hyphenating PLE with HPLC via a turbulent flow chromatography column. The crude sample was placed in a hollow guard column, which was linked to a long narrow polyetheretherketone tube and warmed in the column oven. The extraction solvent was delivered at a high flow rate to generate considerable back pressure. A turbulent flow chromatography column was incorporated to trap the small molecular components and transfer the analytes to HPLC. This system was successfully applied to the analysis of Polygalae Radix [36] and Cistanches Herba [37, 38].
Online coupling of sample preparation with chromatographic method could reduce errors generated through the process and enable automation of TCM quality control that requires minimum human labor. However, research on this kind of techniques is still relatively few, and the applicability to couple different sample preparation methods to different chromatographic methods has to be studied as well.

\section{TLC related techniques}

In present EP and ChP monographs, TLC analysis is used mostly for TCM identification and adulterants differentiation. It is a simple, rapid method which allows the simultaneous analysis of multiple samples in parallel, but suffers from the limitations such as low separation efficiency, poor reproducibility and poor sensitivity in quantification. Nevertheless, with the development of high-performance TLC (HPTLC) and the introduction of modern instrument that can provide standardized conditions, the performance of TLC has been significantly improved. Up to date, TLC and HPTLC has been successfully applied to the quantitative analysis of active ingredients in a series of herbal drugs including Astragali Radix [39], Magnoliae Officinalis Cortex [40] and Glycyrrhizae Radix et Rhizoma [41], etc. In addition, TLC-bioautography that combines TLC separation with bioassay provides a supreme method for the screening of bioactive compounds from herbal drugs directly. It can not only show the activity of the herbal drugs but also reveal which components contribute to the activity. Due to the merits of being simple, convenient and requiring no laborious isolation, TLC-bioautography has been widely employed for screening and identification of herbal drugs components with bioactivity such as anti-microbial [42], acetylcholinesterase inhibition [43, 44], $\alpha$ - and $\beta$-glucosidase inhibition $[45,46]$, free radical scavenging and antioxidation [42, 47]. Actually, ChP has already included TLC-bioautography against 2,2-diphenyl-1-picrylhydrazyl radical for the identification of Rehmanniae Radix. Furthermore, coupling of TLC with MS or LCMS can offer the possibility for on-line identification of the active compound, which enhances the potential of TLC in screening, identification and quantification of active constituents of herbal drugs.

\section{UHPLC and LC-MS}

In recent $\mathrm{LC}$ analysis of $\mathrm{TCM}$, more and more research are done by using UHPLC and LC-MS, which propose a more advanced option for more efficient, accurate and feasible quality control of herbal drugs [48, 49]. UHPLC is an advanced LC technique, which could achieve better separation and performance with shorter runtime compared to conventional HPLC, through revolutionary 
development in LC system especially in the pumps, column and valves, etc. [50]. At present, UHPLC has been included in both pharmacopoeia for component determination in TCM or TCM prescriptions. For example, EP has included UHPLC method for the determination of the total contents of 7 flavonoids in Typhae pollis. ChP has also included UHPLC method for multiple components determination for several Chinese patent medicines, such as Qishen Yiqi dripping pill, Fufang Danshen dripping pill and Hugan capsule. Moreover, hyphenation of LC especially UHPLC with MS, which can provide the structural information of components, could greatly enhance the efficiency and performance in qualitative and quantitative analysis of herbal drugs [48, 49]. For example, LC-MS is utilized for the determination of toosendanin in Toosendan Fructus and Meliae Cortex in ChP. Xiao et al. used UHPLC-MS to identify 131 compounds and quantify seven of them in the fruits, leaves and root barks of Lycium barbarum [51]. Zeng et al. employed UHPLC-triple quadrupole-MS/MS to determine 20 major constituents including salvianolic acids, tanshinones, flavonoids and triterpenes in different parts of Salvia miltiorrhiza [52]. Furthermore, other than active components determination, LC-MS has also been applied in analysis of toxins such as pesticide residue $[53,54]$ and mycotoxins [55-57]. In ChP, LC-MS has been used for the test of adonifoline, a toxic alkaloid in Senecionis Scandentis Herba. EP has included UHPLCMS method in confirmatory test for aristolochic acid I of herbal drugs. As the promotion and popularization of UHPLC and LC-MS, they may be more and more adopted for TCM and herbal drugs in pharmacopoeias.

\section{Headspace (HS) GC-MS}

Nowadays, HS extraction and utilization of MS are widely studied in GC analysis of herbal drugs, and coupling with solid-phase microextraction (SPME) could further enhance the performance, availability and sensitivity of GC analysis [58]. In this technique, the sample is usually heated to make the volatile compounds be transferred to gas phase and then are injected to GC (static HS) or extracted by sorbent (HS-SPME). It has simplified isolation, extraction and concentration in GC analysis into one step, which will require less samples and no organic solvents in analysis [59]. HS-GC has been used for residual solvents in both EP and ChP. However, due to its limitation in precision and accuracy, it is more applied to qualitative or relative quantitative analysis of volatile components in herb drugs. Huang et al. used HSSPME-GC-MS to identify 46 compounds and relatively determine four major volatile components in Zingiberis Rhizoma with different drying methods [60]. Zhang et al. compared the composition and relative contents of the volatile compounds in crude and processed Atractylodis Macrocephalae Rhizoma using static HS-GC-MS [61]. Chen et al. separated and relatively quantified 63 volatile compounds, with 53 being identified from three Dendrobium spp. samples by HS-GC-MS [62].

\section{Quantitative analysis of multi-components by single marker (QAMS)}

It is known that the efficacy of TCM is contributed by their multi-components or in their combinations. Thus multi-components determination has been commonly accepted as the effective way for the quality control of TCM. But the major obstacles of the approach are the lack of commercial available CRS and the high costs involved. In order to resolve the problem, QAMS method that could accurately determine the contents of multiple constituents by using a single compound has been proposed. It uses a commercially available and cheap CRS as the internal standard, then the peaks of other compounds could be identified by relative retention time and the contents could be calculated by the validated relative correction factor [63]. QAMS method has been adopted in several monographs in both pharmacopoeias, such as Andrographis Herba, Aucklandiae Radix and Evodiae Fructus in EP, as well as Andrographis Herba, Coptidis Rhizoma and Salviae Miltiorrhizae Radix et Rhizoma in ChP. It has also been widely used for multi-components quantification of TCM, including Scutellariae Radix [64], Astragali Radix [65], Gastrodiae Rhizoma [66], etc. QAMS is a simple and practical method for simultaneous determination of multi-components in herbal drugs, which is expected to be utilized more widely by pharmacopoeias in the future.

\section{Fingerprint}

Fingerprints are becoming more and more important in quality control especially in authentication and identification of TCM because of their complexity. Using fingerprint could reflect integral characterization of herbal drugs and offer the possibility for TCM quality control in a holistic manner, which is consistent with the principle of traditional Chinese medicine [67]. Hence, EP has already included some GC "chromatographic profile" for essential oil monographs such as Cassia oil, Clove oil and Eucalyptus oil. ChP has included "characteristic chromatogram" or "fingerprint" tests in some TCM and TCM's oil, fat and extractives as well, e.g. Aquilariae Lignum Resinatum, Dendrobii Caulis, Gastrodiae Rhizoma, Notopterygii Rhizoma et Radix, Lonicerae Japonicae Flos, Notoginseng Total Saponins, and Salvia Total Phenolic Acids. Hong Kong Chinese Materia Medica Standards has also included HPLC fingerprint for TCM authentication, and a typical chromatogram is presented 
in the monograph of each TCM. Nowadays, fingerprint could be generated by various analytical techniques including TLC, HPLC/UHPLC, GC, infrared spectroscopy, nuclear magnetic resonance spectroscopy, etc. The combination of chemometric methods such as similarity analysis, principal component analysis and hierarchical cluster analysis can make full use of the component information of fingerprints, which is beneficial to the overall quality control of TCM. Lu et al. established HPLC fingerprint coupled with similarity, hierarchical clustering, and principal component analyses to evaluate the quality of raw and processed Corydalis Rhizoma from different origins [68]. Huang et al. used GC-MS fingerprint combined with chemometric approaches for the discrimination of Schisandrae Fructus from different species and different growing places [69]. Since techniques in fingerprint establishment are becoming more and more mature and easily assessable, inclusion of fingerprint in pharmacopoeia monographs would be more and more often and necessary for better quality control of herbal drugs.

\section{Molecular DNA barcoding}

Besides chemical-based TCM identification, molecular identification that uses specific fragments of DNA as markers is another effective method for authentication and identification of herbal drugs. In ChP, molecular identification has been used for the identification of Dendrobii Caulis, Fritillariae Cirrhosae Bulbus, Agkistrodon, Bungarus Parvus and Zaocys. Among various molecular identification techniques, molecular DNA barcoding has been increasingly studied recently [70, 71]. The core of this advanced technique is to assess the sequence variations of one or several commonly recognized, relatively short DNA sequences in the genome of the samples for the identification and authentication of herbal drugs. The process in general could be divided into three steps: DNA extraction, polymerase chain reaction amplification and DNA sequencing. Then the data are compared, aligned and analyzed to identify and authenticate herbal drugs from adulterants. As DNA barcoding technology is more assessable nowadays, ChP has incorporated a general chapter "9107 Guidelines for molecular DNA barcoding of Chinese materia medica", which provides information and requirements for using DNA barcoding in TCM identification. In recent years, DNA barcoding has been widely used for the authentication and discrimination of TCM with their adulterants, such as Scutellariae Radix [72], Astragali Radix [73], Bupleuri Radix [74], Uncariae Ramulus cum Uncis [75] and Corydalis Rhizoma [76]. Compared to chromatographic methods, DNA barcoding is a more specific technique in herbal drugs identification and is not easily affected by external factors such as climates, age, or plant part. But it may suffer from disadvantages such as false positive or negative results originating from poor DNA quality or wrong choice of DNA markers. Its application is also limited in identifying different medicinal parts, and not suitable for processed TCM because DNA degradation would severely occur in this circumstance [77]. Therefore, combination of chromatographic methods and DNA barcoding may provide comprehensive identification and quality control of TCM.

\section{Conclusions}

In summary, quality control of TCM is very important in TCM application and the complexity of TCM promotes difficulties in quality control and quality standards establishment for TCM. But even so, working parties in EP and ChP have managed to assess TCM quality by regulating the origins, identification, quality parameters (such as moisture content and impurities) and active components contents in TCM. However, there are differences between the pharmacopoeias in Europe and China, including the source of TCM herbs, tests required for TCM, marker selection and assay methods etc. because of the different systems in quality control of TCM, and the application habits of TCM between Europe and China. Nevertheless, improvements may be made in the pharmacopoeias from the experience of the two parties. For example, although ChP (2020 edition) has removed the TCM containing aristolochic acids including Aristolochiae Herba and Aristolochiae Fructus, there are some TCM easily confused with the herbal drugs from Aristolochia species, such as Akebia Stem, Aucklandiae Radix, Clematidis Armandii Caulis, Stephaniae Tetrandrae Radix and Sinomenii Caulis. Including the test for aristolochic acids in these TCM as EP may be necessary and important to avoid the adulteration or misuse of aristolochic acids-containing drugs. On the other hand, in EP, HRS has been used for system suitability assessment of LC assay, it may be utilized for TLC identification as well, specially for the TCM without suitable active markers or lack of commercial available CRS. EP may also include methods of molecular identification and standards for residue of sulfur dioxide for more comprehensive quality control of TCM. Therefore, discussion about these issues and cooperation between different parties are urgently needed to improve and harmonize the quality standard of TCM. With the development in analytical techniques and quality control methods such as improvements in chromatography techniques as well as the application of molecular identification, new 
quality control measures are very likely to be used in the future for better quality assessment of herbal drugs.

\section{Supplementary information}

Supplementary information accompanies this paper at https://doi. org/10.1186/s13020-020-00357-3.

Additional file 1: Table S1. Comparison of herbal drugs recorded in both European Pharmacopoeia and Chinese Pharmacopoeia.

\begin{abstract}
Abbreviations
ChP: Chinese Pharmacopoeia; CRS: Chemical reference substance; EDQM: European Directorate for the Quality of Medicines \& Health Care; EP: European Pharmacopoeia; GC: Gas chromatography; HPLC: High performance liquid chromatography; HPTLC: High performance thin layer chromatography; HRS: Herbal reference substance; HS: Headspace; ICP: Inductively coupled plasma; LC: Liquid chromatography; MS: Mass spectrometry; PLE: Pressurized liquid extraction; QAMS: Quantitative analysis of multi-components by single marker; SPE: Solid phase extraction; SPME: Solid-phase microextraction; TCM: Traditional Chinese medicine; TLC: Thin layer chromatography; UHPLC: Ultra-high performance liquid chromatography; UV-Vis: Ultraviolet-visible spectroscopy.
\end{abstract}

\section{Acknowledgements}

Not applicable.

\section{Authors' contributions}

FL and XH drafted the manuscript and prepared the tables and figure. MW, TC, YS and PT contributed to the critical revisions of the manuscript. XJC designed the study, developed the manuscript and are the corresponding authors. All authors read and approved the final manuscript.

\section{Funding}

This study was financially supported by the funding Grants from University of Macau (File no. SRG2017-00095-ICMS, MYRG2018-00207-ICMS and MYRG201900121-ICMS), The Science and Technology Development Fund, Macau SAR (SKL-QRCM Additional Fund), Guangxi Innovation-driven Development Special Foundation Project (File no. GuiKe AA18118049), and Guangdong Basic and Applied Basic Research Foundation (File no. 2019B1515120043).

\section{Availability of data and materials}

Not applicable.

Ethics approval and consent to participate

Not applicable.

\section{Consent for publication}

Not applicable.

\section{Competing interests}

The authors declare that they have no competing interests.

\section{Author details}

${ }^{1}$ State Key Laboratory of Quality Research in Chinese Medicine, Institute of Chinese Medical Sciences, University of Macau, Avenida da Universidade, Taipa, Macao, People's Republic of China. ${ }^{2}$ LU-European Center for Chinese Medicine and Natural Compounds, Institute of Biology, Leiden University, Sylviusweg72, 2333BE Leiden, The Netherlands. ${ }^{3}$ Science and Technology Innovation Center, Guangzhou University of Chinese Medicine, Guangzhou 510405, China. ${ }^{4}$ Modern Research Center for Traditional Chinese Medicine, School of Chinese Materia Medica, Beijing University of Chinese Medicine, Beijing 100029, China. ${ }^{5}$ State Key Laboratory of Natural and Biomimetic Drugs, School of Pharmaceutical Sciences, Peking University, Beijing 100191, China.

\section{References}

1. World Health Organization. WHO global report on traditional and complementary medicine 2019. Geneva: World Health Organization; 2019.

2. Tang JL, Liu BY, Ma KW. Traditional Chinese medicine. Lancet. 2008;372(9654):1938-40.

3. $\mathrm{Xu}$ J, Yang Y. Traditional Chinese medicine in the Chinese health care system. Health Policy. 2009;90(2-3):133-9.

4. World Health Organization. WHO traditional medicine strategy 2014-2023. Geneva: World Health Organization; 2013.

5. Vanherweghem JL, Depierreux M, Tielemans C, Abramowicz D, Dratwa M, Jadoul M, Richard C, Vandervelde D, Verbeelen D, Vanhaelen-Fastre $R$, Vanhaelen M. Rapidly progressive interstitial renal fibrosis in young women: association with slimming regimen including Chinese herbs. Lancet. 1993;341(8842):387-91.

6. Vanherweghem JL. Misuse of herbal remedies: the case of an outbreak of terminal renal failure in Belgium (Chinese herbs nephropathy). J Altern Complement Med. 1998;4(1):9-13.

7. Ng AWT, Poon SL, Huang MN, Lim JQ, Boot A, Yu W, Suzuki Y, Thangaraju S, Ng CCY, Tan P, Pang ST, Huang HY, Yu MC, Lee PH, Hsieh SY, Chang AY, Teh BT, Rozen SG. Aristolochic acids and their derivatives are widely implicated in liver cancers in Taiwan and throughout Asia. Sci Transl Med. 2017;9(412):eaan6446.

8. van der Valk JMA, Leon CJ, Nesbitt M. Macroscopic authentication of Chinese materia medica (CMM): a UK market study of seeds and fruits. J Herb Med. 2017:8:40-51.

9. Bauer R, Franz G. Modern European monographs for quality control of Chinese herbs. Planta Med. 2010;76(17):2004-11.

10. Wang M, Franz G. The role of the European Pharmacopoeia (Ph Eur) in quality control of traditional Chinese herbal medicine in European member states. World J Tradit Chin Med. 2015;1(1):5-15.

11. Lv X, Li Y, Tang C, Zhang Y, Zhang J, Fan G. Integration of HPLC-based fingerprint and quantitative analyses for differentiating botanical species and geographical growing origins of Rhizoma coptidis. Pharm Biol. 2016;54(12):3264-71.

12. Qi L, Ma Y, Zhong F, Shen C. Comprehensive quality assessment for Rhizoma Coptidis based on quantitative and qualitative metabolic profiles using high performance liquid chromatography, Fourier transform near-infrared and Fourier transform mid-infrared combined with multivariate statistical analysis. J Pharm Biomed Anal. 2018;161:436-43.

13. Wu TJ, Lu J, Ni H, Li P, Jiang Y, Li HJ. Construction of an optimized method for quality evaluation and species discrimination of Coptidis Rhizoma by ion-pair high performance liquid chromatography combined with response surface methodology. J Pharm Biomed Anal. 2018;153:152-7.

14. Zhao B, Huang Y, Chen Q, Chen Q, Miao H, Zhu S, Zeng C. Characteristic component profiling and identification of different Uncaria species based on high-performance liquid chromatography-photodiode array detection tandem ion trap and time of flight mass spectrometry coupled with rDNA ITS sequence. Biomed Chromatogr. 2018;32(3):e4119.

15. Pan H, Yao C, Yao S, Yang W, Wu W, Guo D. A metabolomics strategy for authentication of plant medicines with multiple botanical origins, a case study of Uncariae Rammulus Cum Uncis. J Sep Sci. 2020;43(6):1043-50.

16. Tian F, Shan XL, Ding YJ, Chao JG. Analysis and thinking of Latin synonym phenomena of medicinal plants. Chin Pharm. 2014;25(39):3741-4.

17. Hinz DC. Evaluation of methods for the determination of water in substances with unknown chemical and thermal behaviour. J Pharm Biomed Anal. 2007;43(2):779-83.

18. Yoshii K, Tonogai Y. Water content using Karl-Fisher aquametry and loss on drying determinations using thermogravimeter for pesticide standard materials. J Health Sci. 2004;50(2):142-7.

19. Bolan S, Kunhikrishnan A, Seshadri B, Choppala G, Naidu R, Bolan NS, Ok YS, Zhang M, Li C-G, Li F, Noller B, Kirkham MB. Sources, distribution, bioavailability, toxicity, and risk assessment of heavy metal(loid)s in complementary medicines. Environ Int. 2017;108:103-18.

20. Evans EH, Pisonero J, Smith CMM, Taylor RN. Atomic spectrometry update: review of advances in atomic spectrometry and related techniques. J Anal At Spectrom. 2020;35(5):830-51. 
21. Sadee B, Foulkes M, Hill S. Coupled techniques for arsenic speciation in food and drinking water: a review. J Anal At Spectrom. 2015;30(1):102-18.

22. Bolan S, Naidu R, Kunhikrishnan A, Seshadri B, Ok YS, Palanisami T, Dong M, Clark I. Speciation and bioavailability of lead in complementary medicines. Sci Total Environ. 2016;539:304-12.

23. Liu XJ, Zhao QL, Sun GX, Williams P, Lu XJ, Cai JZ, Liu WJ. Arsenic speciation in Chinese Herbal Medicines and human health implication for inorganic arsenic. Environ Pollut. 2013;172:149-54.

24. Liu L, Zhang Y, Yun Z, He B, Jiang G. Estimation of bioaccessibility and potential human health risk of mercury in Chinese patent medicines. J Environ Sci. 2016;39:37-44.

25. Tang F, Ni Z, Liu Y, Yu Q, Wang Z, Mo R. Arsenic speciation in honeysuckle (Lonicera japonica Thunb.) from China. Biol Trace Elem Res. 2015;168(1):269-75.

26. Jin $P$, Liang $X, X i a ~ L$, Jahouh F, Wang R, Kuang $Y$, Hu X. Determination of 20 trace elements and arsenic species for a realgar-containing traditional Chinese medicine Niuhuang Jiedu tablets by direct inductively coupled plasma-mass spectrometry and high performance liquid chromatography-inductively coupled plasma-mass spectrometry. J Trace Elem Med Biol. 2016;33:73-80.

27. Cao YP, Yan LZ, Huang HL, Deng BY. Determination of selenium species in burdock and Panax notoginseng using ultrasonic assistant extraction combined with high performance liquid chromatographyinductively coupled plasma-mass spectrometry. Chin J Anal Chem. 2015;43(9):1329-34.

28. Jiang $X$, Huang LF, Zheng SH, Chen SL. Sulfur fumigation, a better or worse choice in preservation of Traditional Chinese Medicine? Phytomedicine. 2013;20(2):97-105.

29. Ji C, Fan Y, Zhao L. Review on biological degradation of mycotoxins. Anim Nutr. 2016;2(3):127-33.

30. European Directorate for the Quality of Medicines \& HealthCare. Guide for the elaboration of monographs on herbal drugs and herbal drug preparations. France: Council of Europe; 2007.

31. Azmin SNHM, Manan ZA, Alwi SRW, Chua LS, Mustaffa AA, Yunus NA. Herbal processing and extraction technologies. Sep Purif Rev. 2016;45(4):305-20.

32. Wu X, Wang S, Lu J, Jing Y, Li M, Cao J, Bian B, Hu C. Seeing the unseen of Chinese herbal medicine processing (Paozhi): advances in new perspectives. Chin Med. 2018;13(1):4.

33. Li H, Wang $X$, Liu Y, Pan D, Wang Y, Yang N, Xiang L, Cai X, Feng Y. Hepatoprotection and hepatotoxicity of Heshouwu, a Chinese medicinal herb: context of the paradoxical effect. Food Chem Toxicol. 2017;108:407-18.

34. Jin W, Zhou T, Li G. Recent advances of modern sample preparation techniques for traditional Chinese medicines. J Chromatogr A. 2019;1606:460377.

35. Song Y, Zhang N, Jiang Y, Li J, Zhao Y, Shi S, Tu P. Simultaneous determination of aconite alkaloids and ginsenosides using online solid phase extraction hyphenated with polarity switching ultra-high performance liquid chromatography coupled with tandem mass spectrometry. RSC Adv. 2015;5(9):6419-28.

36. Song Y, Song Q, Li J, Shi S, Guo L, Zhao Y, Jiang Y, Tu P. Chromatographic analysis of Polygalae Radix by online hyphenating pressurized liquid extraction. Sci Rep. 2016:6:1-11.

37. Song Q, Li J, Liu X, Zhang Y, Guo L, Jiang Y, Song Y, Tu P. Home-made online hyphenation of pressurized liquid extraction, turbulent flow chromatography, and high performance liquid chromatography, Cistanche deserticola as a case study. J Chromatogr A. 2016;1438:189-97.

38. Song Q, Liu Y, Zhang L, Zhou L, Tu P, Song Y. Simultaneous determination of three phenylethanoid glycosides in Cistanche tubulosa by online pressurized liquid microextraction-turbulent flow chromatography-high performance liquid chromatography. Chin J Chromatogr. 2016;34(6):572-6.

39. Zhang J, Meng M, Jiang Y, Zhang H, Wang F. A new approach to develop a standardized method for simultaneous analysis of astragaloside IV and formononetin in Radix Astragali by high-performance thin-layer chromatography. J Planar Chromatogr. 2015;28(4):268-73.

40. Gu L, Zheng S, Wu T, Chou G, Wang Z. High-performance thin-layer chromatographic-bioautographic method for the simultaneous determination of magnolol and honokiol in Magnoliae officinalis cortex. J Planar Chromatogr. 2014;27(1):5-10.

41. Alam P, Kamal YT, Alqarni MH, Zaatout HH, Abdel-Kader MS. Reversedphase high-performance thin-layer chromatographic method for the simultaneous determination of glycyrrhizin and glabridin biomarkers in Glycyrrhiza glabra roots, rhizomes and herbal formulations. J Planar Chromatogr. 2018;31(2):135-42.

42. Ristivojević PM, Tahir A, Malfent F, Opsenica DM, Rollinger JM. Highperformance thin-layer chromatography/bioautography and liquid chromatography-mass spectrometry hyphenated with chemometrics for the quality assessment of Morus alba samples. J Chromatogr A. 2019;1594:190-8.

43. Gonzalez EP, Hagenow S, Murillo MA, Stark H, Suarez LC. Isoquinoline alkaloids from the roots of Zanthoxylum rigidum as multi-target inhibitors of cholinesterase, monoamine oxidase $A$ and $A \beta 1-42$ aggregation. Bioorg Chem. 2020;98:103722

44. Czernicka L, Ludwiczuk A, Rój E, Marzec Z, Jarzab A, Kukula-Koch W. Acetylcholinesterase inhibitors among Zingiber officinale terpenes-extraction conditions and thin layer chromatography-based bioautography studies. Molecules. 2020;25(7):1643.

45. Theiler BA, Istvanits S, ZehI M, Marcourt L, Urban E, Caisa LOE, Glasl S. HPTLC bioautography guided isolation of a-glucosidase inhibiting compounds from Justicia secunda Vahl (Acanthaceae). Phytochem Anal. 2017;28(2):87-92.

46. Simões-Pires CA, Hmicha B, Marston A, Hostettmann K. A TLC bioautographic method for the detection of $a$ - and $\beta$-glucosidase inhibitors in plant extracts. Phytochem Anal. 2009;20(6):511-5.

47. Zhang WX, Chao IC, Hu DJ, Shakerian F, Ge L, Liang X, Wang Y, Zhao J, Li SP. Comparison of antioxidant activity and main active compounds among different parts of Alpinia officinarum Hance using highperformance thin layer chromatography-bioautography. J AOAC Int. 2019;102(3):726-33.

48. Wang X, Zhang A, Yan G, Han Y, Sun H. UHPLC-MS for the analytical characterization of traditional Chinese medicines. Trends Anal Chem. 2014;63:180-7.

49. Wu H, Guo J, Chen S, Liu X, Zhou Y, Zhang X, Xu X. Recent developments in qualitative and quantitative analysis of phytochemical constituents and their metabolites using liquid chromatography-mass spectrometry. J Pharm Biomed Anal. 2013;72(Supplement C):267-91.

50. Dong MW, Zhang K. Ultra-high-pressure liquid chromatography (UHPLC) in method development. Trends Anal Chem. 2014;63:21-30.

51. Xiao X, Ren W, Zhang N, Bing T, Liu X, Zhao Z, Shangguan D. Comparative study of the chemical constituents and bioactivities of the extracts from fruits, leaves and root barks of Lycium barbarum. Molecules. 2019;24(8):1585.

52. Zeng H, Su S, Xiang $X$, Sha $X$, Zhu Z, Wang Y, Guo S, Yan H, Qian D, Duan J. Comparative analysis of the major chemical constituents in Salvia miltiorrhiza roots, stems, leaves and flowers during different growth periods by UPLC-TQ-MS/MS and HPLC-ELSD methods. Molecules. 2017;22(5):771.

53. Ma S, Yuan X, Zhao P, Sun H, Ye X, Liang N, Zhao L. Trace determination of five triazole fungicide residues in traditional Chinese medicine samples by dispersive solid-phase extraction combined with ultrasound-assisted dispersive liquid-liquid microextraction and UHPLC-MS/MS. J Sep Sci. 2017;40(16):3257-66.

54. Chen JN, Lian YJ, Zhou YR, Wang MH, Zhang XQ, Wang JH, Wu YN, Wang ML. Determination of 107 pesticide residues in wolfberry with acetatebuffered salt extraction and sin-QuEChERS nano column purification coupled with ultra performance liquid chromatography tandem mass spectrometry. Molecules. 2019;24(16):2918.

55. Zhang S, Lu J, Wang S, Mao D, Miao S, Ji S. Multi-mycotoxins analysis in Pheretima using ultra-high-performance liquid chromatography tandem mass spectrometry based on a modified QuEChERS method. J Chromatogr B Anal Technol Biomed Life Sci. 2016;1035:31-41.

56. Sun S, Yao K, Zhao S, Zheng P, Wang S, Zeng Y, Liang D, Ke Y, Jiang H. Determination of aflatoxin and zearalenone analogs in edible and medicinal herbs using a group-specific immunoaffinity column coupled to ultra-high-performance liquid chromatography with tandem mass spectrometry. J Chromatogr B Anal Technol Biomed Life Sci. 2018;1092:228-36.

57. Huang P, Kong W, Wang S, Wang R, Lu J, Yang M. Multiclass mycotoxins in lotus seeds analysed by an isotope-labelled internal standard-based UPLC-MS/MS. J Pharm Pharmacol. 2018;70(10):1378-88.

58. Deng C, Liu N, Gao M, Zhang X. Recent developments in sample preparation techniques for chromatography analysis of traditional Chinese medicines. J Chromatogr A. 2007;1153(1-2):90-6. 
59. Vyviurska O, Špánik I. Novel sample preparation approaches in gas chromatographic analysis: promising ideas. J Sep Sci. 2020;43(1):174-88.

60. Huang B, Wang G, Chu Z, Qin L. Effect of oven drying, microwave drying, and silica gel drying methods on the volatile components of ginger (Zingiber officinale Roscoe) by HS-SPME-GC-MS. Dry Technol. 2012;30(3):248-55.

61. Zhang J, Cao G, Xia Y, Wen C, Fan Y. Fast analysis of principal volatile compounds in crude and processed Atractylodes macrocephala by an automated static headspace gas chromatography-mass spectrometry. Pharmacogn Mag. 2014;10(39):249-53.

62. Chen ND, You T, Li J, Bai LT, Hao JW, Xu XY. A comparative study of three tissue-cultured Dendrobium species and their wild correspondences by headspace gas chromatography-mass spectrometry combined with chemometric methods. J Food Drug Anal. 2016;24(4):839-47.

63. Gao H, Wang Z, Li Y, Qian Z. Overview of the quality standard research of traditional Chinese medicine. Front Med China. 2011;5(2):195-202.

64. Wang F, Wang B, Wang L, Xiong ZY, Gao W, Li P, Li HJ. Discovery of discriminatory quality control markers for Chinese herbal medicines and related processed products by combination of chromatographic analysis and chemometrics methods: radix Scutellariae as a case study. J Pharm Biomed Anal. 2017;138:70-9.

65. Huang J, Yin L, Dong L, Quan H, Chen R, Hua S, Ma J, Guo D, Fu X. Quality evaluation for Radix Astragali based on fingerprint, indicative components selection and QAMS. Biomed Chromatogr. 2018;32(11):e4343.

66. Li Y, Zhang Y, Zhang Z, Hu Y, Cui X, Xiong Y. Quality evaluation of Gastrodia elata tubers based on HPLC fingerprint analyses and quantitative analysis of multi-components by single marker. Molecules. 2019;24(8):1521.

67. Liu X, Jiang W, Su M, Sun Y, Liu H, Nie L, Zang H. Quality evaluation of traditional Chinese medicines based on fingerprinting. J Sep Sci. 2020;43(1):6-17.

68. Lu Y, Ma Q, Fu C, Chen C, Zhang D. Quality evaluation of Corydalis yanhusuo by high-performance liquid chromatography fingerprinting coupled with multicomponent quantitative analysis. Sci Rep. 2020;10(1):4996.
69. Huang Z, Huang Y, Xu S, Dong W, Pan Z, Wang L. Discrimination of the traditional Chinese medicine from Schisandra Fruits by flash evaporationgas chromatography/mass spectrometry and fingerprint analysis. Chromatographia. 2015;78(15-16):1083-93.

70. Han K, Wang M, Zhang L, Wang C. Application of molecular methods in the identification of ingredients in Chinese herbal medicines. Molecules. 2018;23(10):2728

71. Gao Z, Liu Y, Wang X, Wei X, Han J. DNA mini-barcoding: a derived barcoding method for herbal molecular identification. Front Plant Sci. 2019;10:987.

72. Guo X, Wang X, Su W, Zhang G, Zhou R. DNA barcodes for discriminating the medicinal plant Scutellaria baicalensis (Lamiaceae) and its adulterants. Biol Pharm Bull. 2011;34(8):1198-203.

73. Zheng S, Liu D, Ren W, Fu J, Huang L, Chen S. Integrated analysis for identifying Radix Astragali and its adulterants based on DNA barcoding. Evid based Complement Altern Med. 2014;2014:843923.

74. Chao Z, Zeng W, Liao J, Liu L, Liang Z, Li X. DNA barcoding Chinese medicinal Bupleurum. Phytomedicine. 2014;21(13):1767-73.

75. Tang YL, Wu YS, Huang RS, Chao NX, Liu Y, Xu P, Li KZ, Cai DZ, Luo Y. Molecular identification of Uncaria (Gouteng) through DNA barcoding. Chin Med. 2016;11(1):3.

76. Jiang L, Li M, Zhao F, Chu S, Zha L, Xu T, Peng H, Zhang W. Molecular identification and taxonomic implication of herbal species in genus Corydalis (Papaveraceae). Molecules. 2018;23(6):1393.

77. Abubakar BM, Salleh FM, Omar MSS, Wagiran A. Review: DNA barcoding and chromatography fingerprints for the authentication of botanicals in herbal medicinal products. Evid Based Complement Altern Med. 2017;2017:1352948.

\section{Publisher's Note}

Springer Nature remains neutral with regard to jurisdictional claims in published maps and institutional affiliations.
Ready to submit your research? Choose BMC and benefit from:

- fast, convenient online submission

- thorough peer review by experienced researchers in your field

- rapid publication on acceptance

- support for research data, including large and complex data types

- gold Open Access which fosters wider collaboration and increased citations

- maximum visibility for your research: over $100 \mathrm{M}$ website views per year

At BMC, research is always in progress.

Learn more biomedcentral.com/submissions 